\title{
Synthesis of Phosphonomethylated Bromoacetylfurans and Their Reactions with 1,3-Dicarbonyl Compounds
}

\author{
L. M. Pevzner ${ }^{a, *}$ and A. I. Ponyaev ${ }^{a}$ \\ ${ }^{a}$ St. Petersburg State Institute of Technology (Technical University), St. Petersburg, 190013 Russia \\ *e-mail:pevzner_lm@list.ru
}

Received December 28, 2020; revised December 28, 2020; accepted January 20, 2021

\begin{abstract}
Bromination of (diethoxyphosphorylmethyl)acetylfurans with dioxane dibromide in the mixture of chloroform and acetic acid in presence of traces of hydrogen bromide at room temperature proceeds selectively at the methyl group of ketone does not involving phosphonate group. Obtained bromoacetyl derivatives were used for alkylation of acetoacetic ester and cyclohexan-1,3-dione. Reaction of 1,4-diketone prepared from acetoacetic ester with hydrazine hydrate in ethanol at room temperature leads to formation of furylpyrazines due to aromatization of intermediate azines by means of air oxygen.
\end{abstract}

Keywords: acetylfurans, bromination, 1,3-dicarbonyl compounds, alkylation, keto-enol tautomerism, pyrazines

DOI: $10.1134 / \mathrm{S} 1070363221040101$

As is known, 1,4-diketones are the starting material for the preparation of a large number of various heterocyclic systems. Continuing the study of approaches to the synthesis of furan-containing hybrid heterocyclic systems with a phosphonate group in their structure, we turned to the development of a method for obtaining functionally substituted 1,4-diketones of the furan series, based on the alkylation of 1,3-dicarbonyl compounds with phosphonomethylated bromoacetylfurans.

The currently known assortment of bromoacetylfurans is very limited. 2-Bromacetylfuran is obtained by bromination of acetylfuran with bromine in diethyl ether or in a mixture of diethyl ether and dioxane [1-3]. 3-Bromoacetylfuran was synthesized by bromination of 3-acetylfuran with bromine in the mixtures of acetic acid and toluene, as well as by means of bromination with copper dibromide in the boiling mixture of chloroform and ethyl acetate $[4,5]$. Phosphorus-containing bromoacetylfurans have not yet been obtained. At the same time, the study of bromination of esters of furylmethanephosphonic acids showed [6] that the $\mathrm{P}-\mathrm{C}$ bond is rather easily cleaved by molecular bromine,

Scheme 1.<smiles>CCOCc1ccc(C(C)=O)o1</smiles><smiles>CCOCc1occc1C(C)=O</smiles>

4<smiles>CCOCc1cc(C(C)=O)oc1C</smiles>

2<smiles>CCOCc1cocc1C(C)=O</smiles>

5<smiles>CCOCc1ccoc1C(C)=O</smiles>

$(\mathrm{EtO})$<smiles>CCOCc1cc(C(C)=O)co1</smiles> 
Scheme 2.

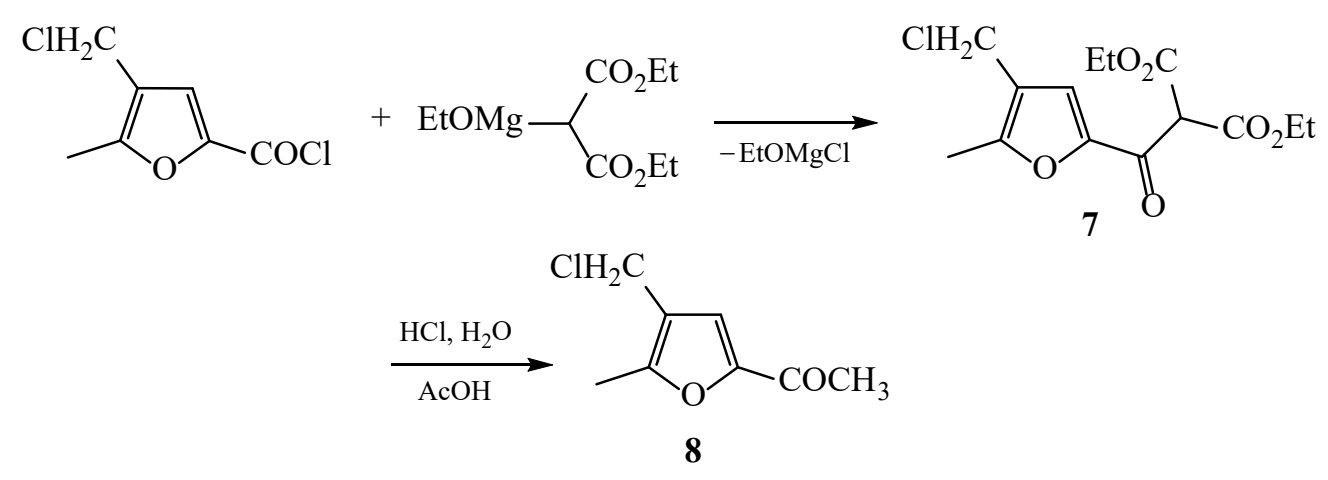

Scheme 3.

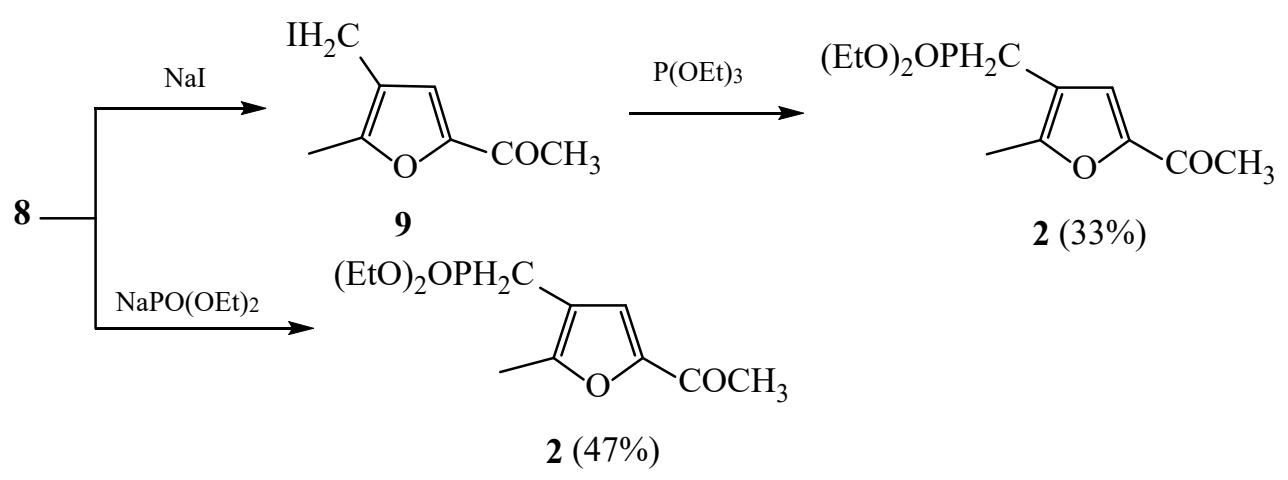

while the action of hydrogen bromide often leads to dealkylation of esters of furylmethanephosphonic acids. Therefore, it is desirable to carry out bromination of phosphonomethylated acetylfurans with complex-bound bromine at low temperatures in media with low acidity.

We have selected compounds $\mathbf{1}-\mathbf{6}$ as starting substances (Scheme 1), the structures of which cover all six possible variants of the relative position of the acetyl and dialkylphosphonomethyl groups in the furan ring. Phosphonates 1, 3, 4, 6 were synthesized by a known method from the corresponding bromides by means of the Arbuzov reaction [7], and for compounds 2 and 5 a method was developed for their synthesis starting from the corresponding known chloromethylfurancarboxylic acids chlorides [8].

By means of the reaction of an ethoxymagnesium derivative of diethylmalonate with 4-chloromethyl-5methyl-2-furoyl chloride in a mixture of absolute ether and absolute ethanol at $10-15^{\circ} \mathrm{C}$ diethyl (4-chloromethyl5-methyl-2-furoyl)malonate 7 (Scheme 2) was prepared in $92 \%$ yield.
Compound 7 exists in solution as the mixture of two conformers. The signal of the proton of the methine group of acylmalonate in the ${ }^{1} \mathrm{H}$ NMR spectrum is observed at $4.40 \mathrm{ppm}$, the signals of the protons of the chloromethyl group appear at 5.00 and $5.03 \mathrm{ppm}$ in the $1: 0.5$ ratio. The signals of the $\mathrm{H}^{3}$ proton of the furan ring are located at 7.05 and $7.25 \mathrm{ppm}$ respectively and have the same intensity ratio. The carbon nucleus of the methine group of the acylmalonate gives two signals at 61.24 (minor) and $61.26 \mathrm{ppm}$ (main). The carbonyl group of the furoyl fragment is represented by two signals at 176.61 (main) and $176.67 \mathrm{ppm}$ (minor). Doubling of signals is also observed for all carbon nuclei of the malonate fragment, as well as for the carbon of the methyl group and the $\mathrm{C}^{2}$, $\mathrm{C}^{4}$ and $\mathrm{C}^{5}$ nuclei of the furan ring.

Heating of compound 7 in a mixture of dilute hydrochloric and acetic acids for $3 \mathrm{~h}$ leads to hydrolysis and decarboxylation of both acid groups of the acylmalonic ester (Scheme 3). Acetylfuran 8 was isolated in $50 \%$ yield.

For the transfer from chloromethylfuran $\mathbf{8}$ to target phosphonate $\mathbf{2}$, two routes were used (Scheme 3). The 




Scheme 5.

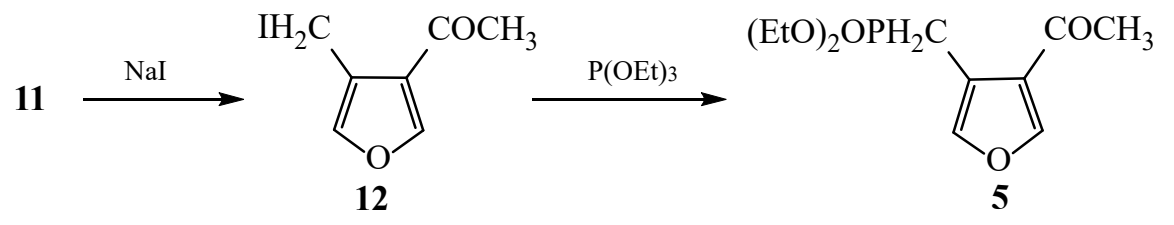

first included the Finkelstein reaction for obtaining of iodomethylfuran 9 and subsequent phosphorylation under the conditions of the Arbuzov reaction. The Finkelstein reaction was carried out in acetone at room temperature using a twofold excess of sodium iodide dihydrate.

Iodomethylfuran 9 was a colorless crystalline substance with $\mathrm{mp} 56^{\circ} \mathrm{C}$. It rapidly emits iodine in the light. The formation of the iodomethyl group was confirmed by the presence of a singlet of methylene protons at $4.20 \mathrm{ppm}$; the signal of the corresponding carbon nucleus was located at $-6.49 \mathrm{ppm}$. The yield of compound 9 was $44 \%$. When it is heated with triethyl phosphite in a molar ratio of $1: 2.4$ at $120^{\circ} \mathrm{C}$, distillation of ethyl iodide begins. Phosphorylation completes within 5 minutes when the temperature of the reaction mixture reaches $160^{\circ} \mathrm{C}$. By distillation of the reaction mixture, the target phosphonate 2 was isolated in 33\% yield. Phosphorylation of compound $\mathbf{8}$ under the conditions of the Michaelis-Becker reaction turned out to be more successful. The reaction was carried out in benzene with a small excess of sodium diethylphosphite at $80^{\circ} \mathrm{C}$ for $9 \mathrm{~h}$. Phosphonate 2 was isolated by distillation in vacuum in $47 \%$ yield.

A similar approach was used for the synthesis of acetylfuran 5. At the first stage, treating of 4-chloromethyl3 -furoyl chloride with an ethoxymagnesium derivative of malonic ether at $10-12{ }^{\circ} \mathrm{C}$ lead to formation of corresponding furoylmalonic ester $\mathbf{1 0}$ in $90 \%$ yield (Scheme 4). This product has no spectrally distinguishable conformers. The signal of the protons of the chloromethyl group is observed at $4.74 \mathrm{ppm}$, and the signal of the corresponding carbon nucleus is located at $36.36 \mathrm{ppm}$.
Signal of the methine proton appears at $4.90 \mathrm{ppm}$, which correlates with the signal of the carbon nucleus at $63.82 \mathrm{ppm}$. Signal of the ketone carbonyl group carbon nucleus is located at $183.23 \mathrm{ppm}$.

When boiling furoylmalonate $\mathbf{1 0}$ in a mixture of acetic and dilute hydrochloric acid, sequential hydrolysis and decarboxylation takes place to form 4-chloromethyl3 -acetylfuran 11, which was isolated in $57 \%$ yield (Scheme 4). The signal of the protons of the methyl group of the ketone is observed at $2.43 \mathrm{ppm}$, the signal of the corresponding carbon nucleus at $28.04 \mathrm{ppm}$, and the signal of the carbon nucleus of the carbonyl group is located at $192.87 \mathrm{ppm}$.

Chloromethyl ketone $\mathbf{1 1}$ was converted to iodide 12 by treating with sodium iodide in acetone at room temperature. The target compound was obtained in $93 \%$ yield (Scheme 5). In its NMR spectra, the signal of the methylene protons of the iodomethyl group is observed at $4.50 \mathrm{ppm}$, and the nucleus of the corresponding carbon atom gives a signal at $-7.16 \mathrm{ppm}$.

Phosphorylation of compound $\mathbf{1 2}$ with triethyl phosphite at the temperature range $115-150^{\circ} \mathrm{C}$ for $10 \mathrm{~min}$ leads to the target phosphonate $\mathbf{5}$ which was obtained in $68 \%$ yield (Scheme 5 ).

Bromination of phosphonates 1-6 was carried out in chloroform-acetic acid mixture (Scheme 6). To create the acidity of the medium sufficient for the enolization of the ketone at the initial moment of the reaction, several drops of $33 \%$ solution of hydrogen bromide in glacial acetic acid were added to the reaction mixture. A preliminarily prepared solution of dioxane dibromide in a mixture of chloroform and excess of dioxane was 
Scheme 6.

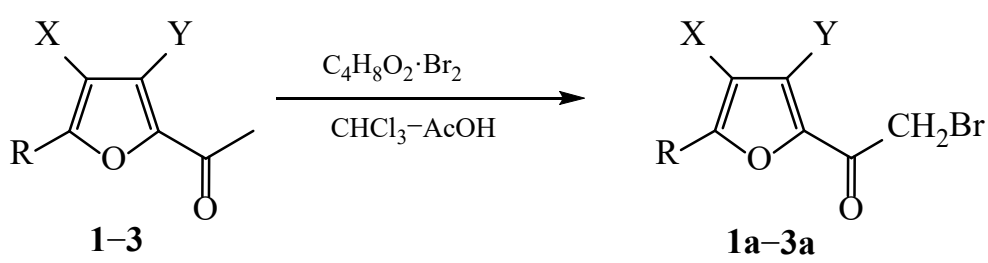

$$
\begin{aligned}
& \mathrm{R}=(\mathrm{EtO})_{2} \mathrm{OPCH}_{2}, \mathrm{X}=\mathrm{Y}=\mathrm{H}(\mathbf{1}, \mathbf{1 a}) ; \mathrm{R}=\mathrm{CH}_{3}, \mathrm{X}=(\mathrm{EtO})_{2} \mathrm{OPCH}_{2}, \\
& \mathrm{Y}=\mathrm{H}(\mathbf{2}, \mathbf{2 a}) ; \mathrm{R}=\mathrm{X}=\mathrm{H}, \mathrm{Y}=(\mathrm{EtO})_{2} \mathrm{OPCH}_{2}(\mathbf{3}, \mathbf{3 a}) .
\end{aligned}
$$

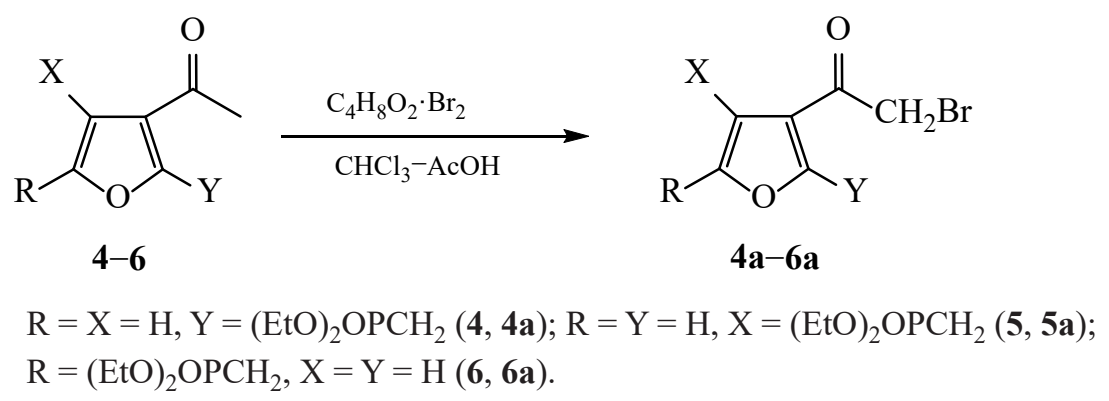

Scheme 7.

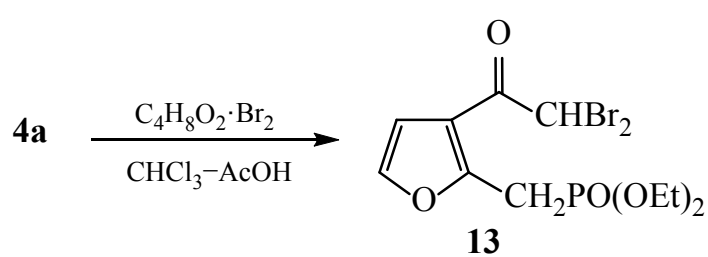

13

used as a brominating agent. The hydrogen bromide released during the reaction is also bound with the excess of dioxane and is deactivated to such an extent that no dealkylation of phosphonates was observed in any case. Bromination was carried out at room temperature by adding dropwise a solution of dioxane dibromide to the ketone solution. The release of heat during the reaction was almost not observed, only in the case of phosphonates 1, 3 and $\mathbf{4}$ the temperature of the reaction mixture rose on $2-3^{\circ} \mathrm{C}$. The disappearance of the color of bromine occurred for phosphonates 2-6 almost at the time of addition; in the case of phosphonate $\mathbf{1}$, it took about $5 \mathrm{~min}$ to decolorize the reaction mixture after the addition of 2-3 drops of dioxane dibromide solution. The yields of bromoacetyl derivatives 1a-6a varied within 84-94\% without a definite dependence on the structure of the substrate. In the case of bromination of phosphonate 4 , the formation of dibromoacetyl derivative $\mathbf{1 3}$ was observed as a minor product. For characterization, it was specially synthesized in $69 \%$ yield by bromination of monobromide 4a under similar conditions (Scheme 7).

The synthesized bromoacetylfurans 1a-6a were used for the alkylation of such typical $\mathrm{CH}$-acids as acetoacetic ester and cyclohexane-1,3-dione. The reaction was carried out in a mixture of absolute dioxane and absolute ethanol in a ratio of $10: 1$; metallization of $\mathrm{CH}$ acids was carried out with freshly prepared sodium ethylate. Alkylation was carried out at $90^{\circ} \mathrm{C}$ for $10 \mathrm{~h}$. In all cases, only monoalkyl derivatives of $\mathrm{CH}$-acids were obtained (Scheme 8).

In the ${ }^{1} \mathrm{H}$ NMR spectra of the products of the alkylation of acetoacetic ester $\mathbf{1 b}-\mathbf{6} \mathbf{b}$, the singlet of protons of the bromoacetyl group in the range 4.2-4.5 ppm disappears, and instead of it there appeas a multiplet at $3.2-3.5 \mathrm{ppm}$. It is the $\mathrm{AB}$ part of $\mathrm{ABX}$-system formed by the signals of the protons of the methylene and methine groups of the alkyl fragment. In all cases, the signal of the proton of the methine group is overlapped by the intense signals of the $\mathrm{OCH}_{2}$ groups, however, two signals are clearly 


\section{Scheme 8.}

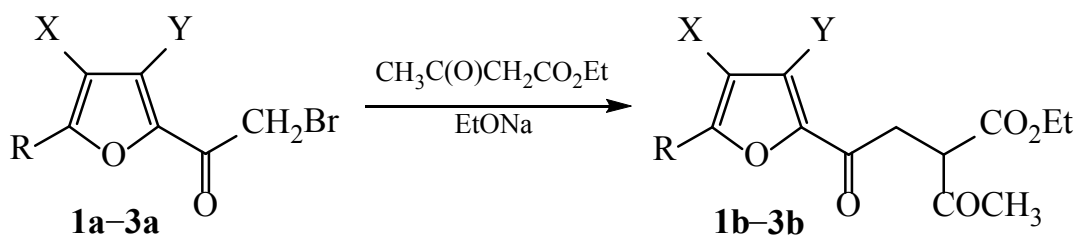

$$
\begin{aligned}
& \mathrm{R}=(\mathrm{EtO})_{2} \mathrm{OPCH}_{2}, \mathrm{X}=\mathrm{Y}=\mathrm{H}(\mathbf{1 a}, \mathbf{1 b}) ; \mathrm{R}=\mathrm{CH}_{3}, \mathrm{X}=(\mathrm{EtO})_{2} \mathrm{OPCH}_{2}, \\
& \mathrm{Y}=\mathrm{H}(\mathbf{2 a}, \mathbf{2} \mathbf{b}) ; \mathrm{R}=\mathrm{X}=\mathrm{H}, \mathrm{Y}=(\mathrm{EtO})_{2} \mathrm{OPCH}_{2}(\mathbf{3 a}, \mathbf{3 b}) .
\end{aligned}
$$

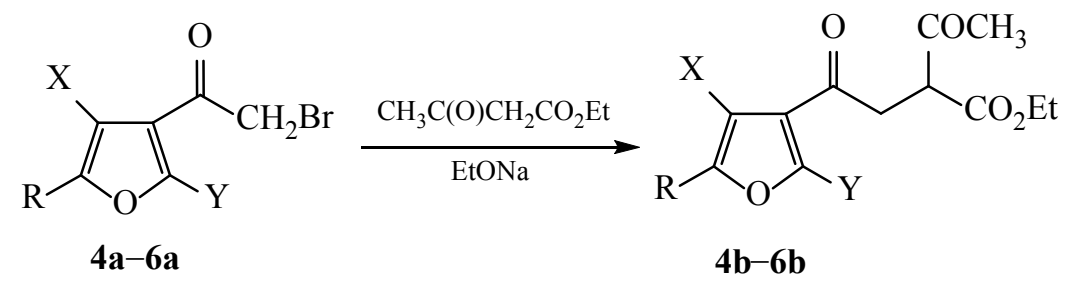

$$
\begin{aligned}
& \mathrm{R}=\mathrm{X}=\mathrm{H}, \mathrm{Y}=(\mathrm{EtO})_{2} \mathrm{OPCH}_{2}(\mathbf{4 a}, \mathbf{4 b}) ; \mathrm{R}=\mathrm{Y}=\mathrm{H}, \mathrm{X}=(\mathrm{EtO})_{2} \mathrm{OPCH}_{2}(\mathbf{5 a}, \mathbf{5 b}) ; \\
& \mathrm{R}=(\mathrm{EtO})_{2} \mathrm{OPCH}_{2}, \mathrm{X}=\mathrm{Y}=\mathrm{H}(\mathbf{6} \mathbf{a}, \mathbf{6 b}) .
\end{aligned}
$$

traced in the carbon spectra at 36.4-38.4 and 53.1$53.5 \mathrm{ppm}$. The first of them corresponds to the methylene carbon atom, and the second to the methine group one. The coupling constant of methylene protons $J_{\mathrm{AB}}$ is 18.0-18.8 Hz. In all cases, the proton giving the upfield signal is denoted $\mathrm{H}_{\mathrm{A}}$, the downfield signal is $\mathrm{H}_{\mathrm{B}}$, and the proton of the methine group is $\mathrm{H}_{\mathrm{X}}$. It turns out that the coupling constant $J_{\mathrm{AX}}$ is in all cases is less than $J_{\mathrm{BX}}$. The average value of the first of them is $5.3 \mathrm{~Hz}$, and of the second one $8.3 \mathrm{~Hz}$. Consequently, the dihedral angle between the $\mathrm{H}_{\mathrm{A}}$ and $\mathrm{H}_{\mathrm{X}}$ nuclei turns out to be larger than that between $\mathrm{H}_{\mathrm{B}}$ and $\mathrm{H}_{\mathrm{X}}$. Thus, the analysis of the spectral characteristics of compounds $\mathbf{1 b}-\mathbf{6 b}$ proves that they all are products of monoalkylation, existing in ketone form. The yields of the alkylation products in the case of 2-bromoacetylfurans $\mathbf{1 a}$ and $\mathbf{2 a}$ with remote substituents are 61 and 54\%, respectively. In the case of 2,3-disubstituted compounds $\mathbf{3 a}$ and $\mathbf{4 a}$, the yield decreases slightly, to 50 and $49 \%$, respectively. In the case of 3,4-disubstituted 3-bromoacetylfuran 5a, the yield is $72 \%$, and its 2,4-disubstituted isomer $\mathbf{6 a}$ gives an alkylation product in $69 \%$ yield. From that it follows that 3-bromoacetylfurans, in which the bulky diethoxyphosphorylmethyl group is in the position 4 or 5 of the furan ring, react more easily with acetoacetic ether than 2-bromoacetylfurans with remote substituents, and 2,3-disubstituted compounds are the least active regardless of the location bromoacetyl group. However, these differences turn out to be very small.
An entirely different picture is observed in the NMR spectra of the alkylation products of cyclohexane-1,3dione (Scheme 9). The signals of the protons of the $\mathrm{CH}_{2} \mathrm{CO}$-furan fragment represent an $\mathrm{AB}$ system, and the value of the $J_{\mathrm{AB}}$ coupling constant in compounds $\mathbf{1 c}$, 3c, $4 \mathbf{c}$ is $12.4,14.2$, and $14.4 \mathrm{~Hz}$, respectively, and in compound $\mathbf{6 c}, 4.0 \mathrm{~Hz}$. Compound $\mathbf{2 c}$ exists in the form of two spectrally distinguishable conformers, the $J_{\mathrm{AB}}$ constants in them are equal to 9.2 and $3.6 \mathrm{~Hz}$, respectively. The signal of the carbon nucleus of the methylene group in the compounds under consideration is in the range $36.5-41.5 \mathrm{ppm}$, which corresponds to the value observed for the products of the alkylation of acetoacetic ester. On the contrary, instead of the signal at $66-67 \mathrm{ppm}$, which is characteristic of the carbon nucleus of the methine group, in the spectra of the alkylation products of acetylacetone [9], two signals are observed in the intervals 110 115 and 186-191 ppm, respectively. In the ${ }^{1} \mathrm{H}$ NMR spectra of compounds $\mathbf{2 c - 4 c}$ a signal is observed at $8.05-8.20 \mathrm{ppm}$. In the spectrum of compound $\mathbf{1 c}$, it shifts to $7.6 \mathrm{ppm}$. The above-presented data show that the alkylation products of cyclohexane-1,3-dione exist in the monoenol form. The narrowness of the signal of the proton of the hydroxyl group and its upfield location non-typical for enols can be explained by the formation of a hydrogen bond between this proton and the oxygen of the carbonyl group bound to the furan ring. The yields of alkylation products in the case of 2-bromoacetylfurans 1a and 2a with substituents distant from the reaction 
Scheme 9.<smiles>[R]c1oc(C(=O)CBr)c([Y])c1[X]</smiles>

$\mathbf{1 a}-\mathbf{3 a}$<smiles>[R]c1oc(C(=O)CC2=C(O)CCCC2=O)c([Y])c1[X]</smiles>

$\mathbf{1 B}-\mathbf{3 C}$

$$
\begin{aligned}
& \mathrm{R}=(\mathrm{EtO})_{2} \mathrm{OPCH}_{2}, \mathrm{X}=\mathrm{Y}=\mathrm{H}(\mathbf{1} \mathbf{a}, \mathbf{1 c}) ; \mathrm{R}=\mathrm{CH}_{3}, \mathrm{X}=(\mathrm{EtO})_{2} \mathrm{OPCH}_{2} \\
& \mathrm{Y}=\mathrm{H}(\mathbf{2 a}, \mathbf{2 c}) ; \mathrm{R}=\mathrm{X}=\mathrm{H}, \mathrm{Y}=(\mathrm{EtO})_{2} \mathrm{OPCH}_{2}(\mathbf{3 a}, \mathbf{3 c})
\end{aligned}
$$<smiles>[R]c1oc([Y])c(C(=O)CBr)c1[X]</smiles>

$4 a, 6 a$

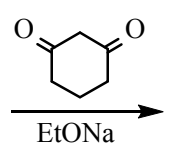

Scheme 10.<smiles>[R]c1oc(C(=O)CC(C(=O)OC)C(=O)OCC)c([Y])c1[X]</smiles>

1b, 2b<smiles>[R]c1oc(-c2cc(C(=O)OCC)c(C)nn2)c([Y])c1[X]</smiles>

1d, 2d<smiles>[R]c1oc([Y])c(C(=O)CC2=C(O)CCCC2=O)c1[X]</smiles>

$4 c, 6 c$

$\mathrm{R}=(\mathrm{EtO})_{2} \mathrm{OPCH}_{2}, \mathrm{X}=\mathrm{Y}=\mathrm{H}(\mathbf{1} \mathbf{b}, \mathbf{1 d}) ; \mathrm{R}=\mathrm{CH}_{3}, \mathrm{X}=(\mathrm{EtO})_{2} \mathrm{OPCH}_{2}$, $\mathrm{Y}=\mathrm{H}(\mathbf{2} \mathbf{b}, \mathbf{2 d})$.<smiles>[R]c1oc([Y])c(C(=O)CC(C(C)=O)C(=O)OCC)c1[X]</smiles>

$4 b-6 b$<smiles>[R]c1oc([Y])c(-c2cc(C(=O)OCC)c(C)nn2)c1[X]</smiles>

4d-6d

$$
\begin{aligned}
& \mathrm{R}=\mathrm{X}=\mathrm{H}, \mathrm{Y}=(\mathrm{EtO})_{2} \mathrm{OPCH}_{2}(\mathbf{4 b}, \mathbf{4 d}) ; \mathrm{R}=\mathrm{Y}=\mathrm{H}, \mathrm{X}=(\mathrm{EtO})_{2} \mathrm{OPCH}_{2}(\mathbf{5 b}, \mathbf{5 d}), \\
& \mathrm{R}=(\mathrm{EtO})_{2} \mathrm{OPCH}_{2}, \mathrm{X}=\mathrm{Y}=\mathrm{H}(\mathbf{6 b}, \mathbf{6 d}) .
\end{aligned}
$$

center are in the range of 36-46\%. On the contrary, in the case of 3-substituted 2-bromoacetylfuran 3a, the yield of the target product turns out to be $81 \%$, that is, two times higher, although they differ little during the alkylation of acetoacetic ether. In the case of 3-bromoacetylfurans 4a and 6a, the opposite picture is observed. The yield of the alkylation product $4 \mathbf{c}$ turns out to be $29 \%$, and of compound $\mathbf{6 c}$, $63 \%$, i.e., the tendency observed in the alkylation of acetoacetic ester remains.

The obtained esters of 2-acetyl-3-furyl-3-oxobutanoic acid $\mathbf{1 b}-\mathbf{6} \mathbf{b}$ were reacted with hydrazine hydrate in order to obtain cyclic diazines (Scheme 10). The reaction was carried out in ethanol at room temperature for 12-15 h. It turned out that under the action of atmospheric oxygen, 
diazine aromatization immediately occurs with the formation of esters of 3-methyl-6-furylpyridazine-4carboxylic acids $\mathbf{1 d}, \mathbf{2 d}$, and $\mathbf{4 d - 6 d}$. In the reaction of compound $\mathbf{3 b}$ with hydrazine hydrate in air, a complex mixture of products is formed, which could not be separated.

In the ${ }^{1} \mathrm{H}$ NMR spectra of the synthesized compounds, the signals of the protons of the $\mathrm{COCH}_{2} \mathrm{CH}$ fragment disappear and a singlet appears at 7.6-8.1 ppm, which was assigned to the $\mathrm{H}^{5}$ proton of the pyridazine ring. In the ${ }^{13} \mathrm{C}$ NMR spectra the signals located in the intervals 141-146 $\left(C^{3}\right), 128.2-128.7\left(C^{4}\right), 121-124\left(C^{5}\right)$, and 137-140 ppm $\left(\mathrm{C}^{6}\right)$ are observed. Since all the signals of the carbon nuclei of the furan ring are split from phosphorus, the attribution of the above-presented signals to the pyridazine ring can be made unambiguously. The observed values of chemical shifts are in good agreement with the data published for esters of 3-methylpyridazine-4-carboxylic acid and their isomers $[10,11]$. The composition of compound $\mathbf{5 d}$ was confirmed by high-resolution mass spectrometry. There is no definite dependence of the yield of pyridazines $\mathbf{1 d}$, $\mathbf{2 d}, \mathbf{4 d}-\mathbf{6 d}$ on the structure of the furan fragment. It should only be noted that compound $\mathbf{5 d}$ with a 3,4-disubstituted furan fragment was isolated in $74 \%$ yield, while in other cases it varied within $28-53 \%$.

Thus, the bromination of phosphorylated acetylfurans with complex-bound bromine in weakly acidic media proceeds at the acetyl group. The dialkoxyphosphorylmethyl moiety is not touched in this case. The obtained bromoacetyl compounds smoothly alkylate such $\mathrm{CH}$-acids as acetoacetic ester and cyclohexane-1,3-dione to form only the products of monoalkylation.

Derivatives of acetoacetic ether exist exclusively in ketone form, and derivatives of cyclohexane-1,3-dione in the form of monoenols. In reaction with hydrazine hydrate, esters of 2-acetyl-4-[(diethoxyphosphorylmethyl)furyl)]-4-oxobutanoic acids give cyclic diazines, which are immediately oxidized with atmospheric oxygen to 6-furylpyridazine-4-carboxylic acid esters.

\section{EXPERIMENTAL}

${ }^{1} \mathrm{H},{ }^{13} \mathrm{C}$, and ${ }^{31} \mathrm{P}$ NMR spectra were recorded on the Bruker AVANCE-400 [400.13 $\left({ }^{1} \mathrm{H}\right), 161.97\left({ }^{31} \mathrm{P}\right), 1$ $\left.00.16 \mathrm{MHz}\left({ }^{13} \mathrm{C}\right)\right]$ NMR spectrometer. Mass spectrum (ESI) was obtained on the Bruker MicrOTOF device.

(4-Chloromethyl-5-methyl-2-furoyl)malonic acid diethyl ester (7). A small crystal of iodine was added to a mixture of $3.9 \mathrm{~mL}$ of malonic ester, $4.7 \mathrm{~mL}$ of absolute ethanol, and $0.78 \mathrm{~g}$ of magnesium turnings and the mixture was heated with stirring until a violent reaction began. The temperature of the reaction mixture was maintained within the range of $80-85^{\circ} \mathrm{C}$ by periodically cooling it with cold water. After the termination of heat evolution, it was heated at the same temperature for another $1 \mathrm{~h}$. The resulting mixture was cooled to $40-45^{\circ} \mathrm{C}$, and then absolute diethyl ether was added until the crystallized ethoxymagnesium derivative was completely dissolved. The resulting mixture was boiled with stirring until the magnesium was completely dissolved, cooled to $10^{\circ} \mathrm{C}$, and a solution of $4.04 \mathrm{~g}$ of 4-chloromethyl-5-methyl-2furoyl chloride in $10 \mathrm{~mL}$ of absolute ether was added dropwise, maintaining the temperature of the reaction mixture at $10-15^{\circ} \mathrm{C}$. The resulting solution was stirred for another $2 \mathrm{~h}$ and left overnight. On the next day, the reaction mixture was decomposed with $20 \%$ sulfuric acid until the precipitate formed overnight was completely dissolved. The organic layer was separated, washed with $20 \mathrm{~mL}$ of water, $20 \mathrm{~mL}$ of $\mathrm{NaCl}$ solution and dried with sodium sulfate. After removing the solvent and excess malonate in a vacuum, $6.09 \mathrm{~g}(92 \%)$ of the target product was obtained in the form of a colorless, highly viscous oil (conformer ratio $1: 0.5) .{ }^{1} \mathrm{H}$ NMR spectrum $\left(\mathrm{CDCl}_{3}\right)$, $\delta$, ppm: common signals: $1.24 \mathrm{t}\left(6 \mathrm{H}, \mathrm{CH}_{3}\right.$-ester, $J_{\mathrm{HH}}=$ $7.2 \mathrm{~Hz}), 2.38 \mathrm{~s}\left(3 \mathrm{H}, \mathrm{CH}_{3}\right.$-furan $), 4.23 \mathrm{q}\left(4 \mathrm{H}, \mathrm{CH}_{2} \mathrm{O}, J_{\mathrm{HH}}=\right.$ $7.2 \mathrm{~Hz}), 4.40$ br.s $(1 \mathrm{H}, \mathrm{CH})$; main conformer: $5.00 \mathrm{~s}(2 \mathrm{H}$, $\left.\mathrm{CH}_{2} \mathrm{Cl}\right), 7.05 \mathrm{~s}\left(1 \mathrm{H}, \mathrm{H}^{3}\right.$-furan); minor conformer: $5.03 \mathrm{~s}$ $\left(2 \mathrm{H}, \mathrm{CH}_{2} \mathrm{Cl}\right), 7.25 \mathrm{~s}\left(1 \mathrm{H}, \mathrm{H}^{3}\right.$-furan). ${ }^{13} \mathrm{C} \mathrm{NMR}$ spectrum $\left(\mathrm{CDCl}_{3}\right), \delta_{\mathrm{C}}, \mathrm{ppm}$ : main conformer: $12.11\left(\mathrm{CH}_{3}\right.$-furan $)$, $13.93\left(\mathrm{CH}_{3}\right.$-ester $), 36.14\left(\mathrm{CH}_{2} \mathrm{Cl}\right), 61.26(\mathrm{CH}), 62.29$ $\left(\mathrm{CH}_{2} \mathrm{O}\right), 117.76\left(\mathrm{C}^{3}\right.$-furan $), 120.66\left(\mathrm{C}^{4}\right.$-furan $), 149.04$ ( $\mathrm{C}^{2}$-furan). 156.59 ( $\mathrm{C}^{5}$-furan), $164.46(\mathrm{C}=\mathrm{O}$-malonate), $176.61(\mathrm{C}=\mathrm{O}$-furan $)$; minor conformer: $12.27\left(\mathrm{CH}_{3}-\right.$ furan), $13.84\left(\mathrm{CH}_{3}\right.$-ester $), 36.14\left(\mathrm{CH}_{2} \mathrm{Cl}\right), 61.24(\mathrm{CH})$, $62.35\left(\mathrm{CH}_{2} \mathrm{O}\right), 117.76\left(\mathrm{C}^{3}\right.$-furan $), 120.61\left(\mathrm{C}^{4}\right.$-furan $)$, 149.20 ( $\mathrm{C}^{2}$-furan). $156.56\left(\mathrm{C}^{5}\right.$-furan $), 164.39(\mathrm{C}=\mathrm{O}$ malonate), 176.67 ( $\mathrm{C}=\mathrm{O}$-furan).

4-Chloromethyl-5-methyl-2-acetylfuran (8). Furoylmalonate $7(12.30 \mathrm{~g})$ was dissolved in a mixture of $40 \mathrm{~mL}$ of glacial acetic acid, $10 \mathrm{~mL}$ of water, and $6 \mathrm{~mL}$ of concentrated hydrochloric acid and heated with stirring for $3 \mathrm{~h}$ at $90^{\circ} \mathrm{C}$. The resulting mixture was poured into $120 \mathrm{~mL}$ of water, saturated with sodium chloride, and extracted with chloroform $(3 \times 20 \mathrm{~mL})$. The extract was washed with water, $\mathrm{NaCl}$ solution, and dried with sodium sulfate. By distillation in a vacuum $3.36 \mathrm{~g}(50 \%)$ of compound $\mathbf{8}$ with bp $107-108^{\circ} \mathrm{C}(1 \mathrm{mmHg})$ was 
obtained. ${ }^{1} \mathrm{H}$ NMR spectrum $\left(\mathrm{CDCl}_{3}\right), \delta$, ppm: $2.37 \mathrm{~s}(3 \mathrm{H}$, $\mathrm{CH}_{3}$-furan), $2.38 \mathrm{~s}\left(3 \mathrm{H}, \mathrm{CH}_{3}\right.$-ketone), $4.41 \mathrm{~s}\left(2 \mathrm{H}, \mathrm{CH}_{2} \mathrm{Cl}\right)$, $7.12 \mathrm{~s}\left(1 \mathrm{H}, \mathrm{H}^{3}\right.$-furan $) .{ }^{13} \mathrm{C}$ NMR spectrum $\left(\mathrm{CDCl}_{3}\right), \delta_{\mathrm{C}}$, ppm: $12.13\left(\mathrm{CH}_{3}\right.$-furan $), 25.67\left(\mathrm{CH}_{3}\right.$-ketone $), 36.51$ $\left(\mathrm{CH}_{2} \mathrm{Cl}\right), 119.20\left(\mathrm{C}^{3}\right.$-furan $), 119.68\left(\mathrm{C}^{4}\right.$-furan $), 150.72$ ( $\mathrm{C}^{2}$-furan), $155.47\left(\mathrm{C}^{5}\right.$-furan $), 195.95(\mathrm{C}=\mathrm{O})$.

4-Iodomethyl-5-methyl-2-acetylfuran (9). To a solution of $4.00 \mathrm{~g}$ of sodium iodide dihydrate in $25 \mathrm{~mL}$ of acetone $1.92 \mathrm{~g}$ of chloromethylfuran $\mathbf{8}$ was added. After mixing of reagents precipitation of sodium chloride began immediately. The reaction mixture was left for $12 \mathrm{~h}$ at room temperature in the dark, then poured into $100 \mathrm{~mL}$ of $10 \%$ sodium sulfite solution, shaken, and extracted with chloroform $(3 \times 20 \mathrm{~mL})$. The extract was washed with $20 \mathrm{~mL}$ of $10 \%$ sodium sulfite solution, $20 \mathrm{~mL}$ of water, $20 \mathrm{~mL}$ of $\mathrm{NaCl}$ solution, dried with sodium sulfate in the dark, and then evaporated. Yield $1.30 \mathrm{~g}(44 \%), \mathrm{mp} .56^{\circ} \mathrm{C}$. ${ }^{1} \mathrm{H}$ NMR spectrum $\left(\mathrm{CDCl}_{3}\right), \delta$, ppm: $2.29 \mathrm{~s}\left(3 \mathrm{H}, \mathrm{CH}_{3^{-}}\right.$ furan), $2.41 \mathrm{~s}\left(3 \mathrm{H}, \mathrm{CH}_{3}\right.$-ketone), $4.20 \mathrm{~s}\left(2 \mathrm{H}, \mathrm{CH}_{2} \mathrm{I}\right), 7.10 \mathrm{~s}$ $\left(1 \mathrm{H}, \mathrm{H}^{3}\right.$-furan $) .{ }^{13} \mathrm{C}$ NMR spectrum $\left(\mathrm{CDCl}_{3}\right), \delta_{\mathrm{C}}$, ppm: -6.93 $\left(\mathrm{CH}_{2} \mathrm{I}\right), 12.35\left(\mathrm{CH}_{3}\right.$-furan $), 25.73\left(\mathrm{CH}_{3}\right.$-ketone $)$, 119.37 ( $\mathrm{C}^{3}$-furan), 121.105 ( $\mathrm{C}^{4}$-furan $), 150.43\left(\mathrm{C}^{2}\right.$-furan), 154.63 ( $\mathrm{C}^{5}$-furan), $186.00(\mathrm{C}=\mathrm{O})$.

4-(Diethoxyphosphorylmethyl)-5-methyl-2-acetylfuran (2). a. By means of the Arbuzov reaction. A mixture of $1.30 \mathrm{~g}$ of iodide 9 and $2 \mathrm{~mL}$ of triethyl phosphite was heated with stirring. At $120^{\circ} \mathrm{C}$, the distillation of ethyl iodide began. The temperature of the reaction mixture was gradually raised to $160^{\circ} \mathrm{C}$, until the release of ethyl iodide was completed. The reaction time was about $5 \mathrm{~min}$. Distillation of the reaction mixture gave $0.45 \mathrm{~g} \mathrm{(33 \% )} \mathrm{of} \mathrm{phosphonate} 2$, bp $165^{\circ} \mathrm{C}$ $(1 \mathrm{mmHg}) .{ }^{1} \mathrm{H}$ NMR spectrum $\left(\mathrm{CDCl}_{3}\right), \delta$, ppm: $1.25 \mathrm{t}$ $\left(6 \mathrm{H}, \mathrm{CH}_{3}\right.$-posphonate, $\left.J_{\mathrm{HH}}=7.2 \mathrm{~Hz}\right), 2.31 \mathrm{~d}\left(3 \mathrm{H}, \mathrm{CH}_{3^{-}}\right.$ furan, $\left.J_{\mathrm{PH}}=3.2 \mathrm{~Hz}\right), 2.37 \mathrm{~s}\left(3 \mathrm{H}, \mathrm{CH}_{3}\right.$-ketone $), 2.84 \mathrm{~d}$ $\left(2 \mathrm{H}, \mathrm{CH}_{2} \mathrm{P}, J_{\mathrm{PH}}=20.4 \mathrm{~Hz}\right), 4.04$ d.q $\left(4 \mathrm{H}, \mathrm{CH}_{2} \mathrm{O}, J_{\mathrm{PH}}=\right.$ $\left.15.2 \mathrm{~Hz}, J_{\mathrm{HH}}=7.2 \mathrm{~Hz}\right), 7.10 \mathrm{~s}\left(1 \mathrm{H}, \mathrm{H}^{3}\right.$-furan $) .{ }^{13} \mathrm{C}$ NMR spectrum $\left(\mathrm{CDCl}_{3}\right), \delta_{\mathrm{C}}$, ppm: $12.11 \mathrm{~d}\left(\mathrm{CH}_{3}\right.$-furan, $\left.{ }^{4} J_{\mathrm{PC}}=1.5 \mathrm{~Hz}\right), 16.41 \mathrm{~d}\left(\mathrm{CH}_{3}\right.$-phosphonate, $\left.{ }^{3} J_{\mathrm{PC}}=5.9 \mathrm{~Hz}\right)$, $23.17 \mathrm{~d}\left(\mathrm{CH}_{2} \mathrm{P},{ }^{1} J_{\mathrm{PC}}=143.5 \mathrm{~Hz}\right), 25.61\left(\mathrm{CH}_{3}\right.$-ketone $)$, $62.60 \mathrm{~d}\left(\mathrm{CH}_{2} \mathrm{O},{ }^{2} J_{\mathrm{PC}}=6.7 \mathrm{~Hz}\right), 112.81 \mathrm{~d}\left(\mathrm{C}^{4}\right.$-furan, $\left.{ }^{2} J_{\mathrm{PC}}=9.3 \mathrm{~Hz}\right), 120.67\left(\mathrm{C}^{3}\right.$-furan $), 150.42\left(\mathrm{C}^{2}\right.$-furan $)$, $155.10 \mathrm{~d}\left(\mathrm{C}^{5}\right.$-furan, $\left.{ }^{3} J_{\mathrm{PC}}=10.2 \mathrm{~Hz}\right), 185.91(\mathrm{C}=\mathrm{O}) .{ }^{31} \mathrm{P}$ NMR spectrum $\left(\mathrm{CDCl}_{3}\right), \delta_{\mathrm{P}}$, ppm: 25.63 .

b. By means of the Michaelis-Becker reaction. To a solution of sodium diethyl phosphite prepared from $0.5 \mathrm{~g}$ of sodium and $3.5 \mathrm{~mL}$ of diethyl hydrogen phosphite in $20 \mathrm{~mL}$ of benzene, a solution of $3.36 \mathrm{~g}$ of chloride
8 in $5 \mathrm{~mL}$ of benzene was added in one portion. The reaction mixture was boiled with stirring for $10 \mathrm{~h}$, cooled to room temperature and washed with $10 \mathrm{~mL}$ of water. The aqueous layer was washed with $10 \mathrm{~mL}$ of benzene, the combined organic phases were washed with $15 \mathrm{~mL}$ of brine and dried over sodium sulfate. Distillation in a vacuum gave $2.52 \mathrm{~g}(47 \%)$ of phosphonate 2 with bp $165^{\circ} \mathrm{C}(1 \mathrm{mmHg})$. The NMR spectra are identical to those given above.

Diethyl (4-chloromethyl-3-furoyl)malonate (10). To a mixture of $2.6 \mathrm{~mL}$ of malonic ether and $3 \mathrm{~mL}$ of absolute ethanol $0.52 \mathrm{~g}$ of magnesium turnings and a small crystal of iodine was added. The resulting mixture was heated until the beginning of a vigorous reaction, and then the temperature was maintained within the range of $80-85^{\circ} \mathrm{C}$ by external cooling. After the completion of heat evolution, the reaction mixture was boiled for $1 \mathrm{~h}$, cooled to $40-45^{\circ} \mathrm{C}$, and absolute ether was added until the crystallized ethoxymagnesium derivative of malonic ether was completely dissolved. The resulting solution was boiled for 3-4 h until the complete dissolution of magnesium, cooled to $10^{\circ} \mathrm{C}$, and at this temperature, a solution of $2.55 \mathrm{~g}$ of 4-chloromethyl-3-furoyl chloride in $5 \mathrm{~mL}$ of absolute ether was added dropwise with stirring. The resulting mixture was stirred at room temperature for $1 \mathrm{~h}$ and left overnight. On the next day, the reaction mixture was decomposed with $20 \%$ sulfuric acid until the precipitate formed overnight was completely dissolved. The organic layer was separated, washed with water, $\mathrm{NaCl}$ solution and dried over sodium sulfate. The solvents and excess malonate were distilled off in a vacuum, the residue obtained was the target product, yield $3.88 \mathrm{~g}$ (90\%), a light syrup. ${ }^{1} \mathrm{H}$ NMR spectrum $\left(\mathrm{CDCl}_{3}\right), \delta$, ppm: $1.28 \mathrm{t}\left(6 \mathrm{H}, \mathrm{CH}_{3}\right.$-ester, $\left.J_{\mathrm{HH}}=7.2 \mathrm{~Hz}\right), 4.28 \mathrm{q}\left(4 \mathrm{H}, \mathrm{CH}_{2} \mathrm{O}\right.$ ester, $\left.J_{\mathrm{HH}}=7.2 \mathrm{~Hz}\right), 4.74 \mathrm{~d}\left(2 \mathrm{H}, \mathrm{CH}_{2} \mathrm{Cl},{ }^{4} J_{\mathrm{HH}}=1.2 \mathrm{~Hz}\right)$, $4.90 \mathrm{~s}(1 \mathrm{H}, \mathrm{CH}), 7.56$ d.t $\left(1 \mathrm{H}, \mathrm{H}^{5}\right.$-furan, ${ }^{4} J_{\mathrm{HH}}=1.2 \mathrm{~Hz}$, $1.6 \mathrm{~Hz}), 8.06 \mathrm{~d}\left(1 \mathrm{H}, \mathrm{H}^{2}\right.$-furan, $\left.{ }^{4} J_{\mathrm{HH}}=1.6 \mathrm{~Hz}\right) .{ }^{13} \mathrm{C} \mathrm{NMR}$ spectrum $\left(\mathrm{CDCl}_{3}\right), \delta_{\mathrm{C}}, \mathrm{ppm}: 13.93\left(\mathrm{CH}_{3}\right.$-ester $), 36.36$ $\left(\mathrm{CH}_{2} \mathrm{Cl}\right), 62.62\left(\mathrm{CH}_{2} \mathrm{O}\right.$-ester $), 63.82(\mathrm{CH}), 123.14\left(\mathrm{C}^{4}-\right.$ furan $), 124.15$ ( $\mathrm{C}^{3}$-furan $), 143.69\left(\mathrm{C}^{5}\right.$-furan $), 149.75\left(\mathrm{C}^{2}\right.$ furan), $164.20(\mathrm{C}=\mathrm{O}-$ malonate $), 183.23(\mathrm{C}=\mathrm{O}-$ ketone $)$.

4-Chloromethyl-3-acetylfuran (11). A mixture of $3.88 \mathrm{~g}$ of acylmalonate $\mathbf{1 0}, 15 \mathrm{~mL}$ of glacial acetic acid, $2 \mathrm{~mL}$ of water, and $2 \mathrm{~mL}$ of concentrated hydrochloric acid was stirred for $4 \mathrm{~h}$ at $80^{\circ} \mathrm{C}$. After that, the reaction mixture was diluted with $50 \mathrm{~mL}$ of water, the solution was saturated with sodium chloride and extracted with chloroform $(3 \times 15 \mathrm{~mL})$. The extract was washed with 
$20 \mathrm{~mL}$ of water, $10 \mathrm{~mL}$ of brine and dried with sodium sulfate. Distillation in a vacuum gave $1.15 \mathrm{~g}(57 \%)$ of the target product $11, \mathrm{bp} 95^{\circ} \mathrm{C}(1 \mathrm{mmHg}), \mathrm{mp} .45^{\circ} \mathrm{C}$. ${ }^{1} \mathrm{H}$ NMR spectrum $\left(\mathrm{CDCl}_{3}\right), \delta$, ppm: $2.42 \mathrm{~s}\left(3 \mathrm{H}, \mathrm{CH}_{3}\right)$, 4.73 br.s $\left(2 \mathrm{H}, \mathrm{CH}_{2} \mathrm{Cl}\right), 7.51$ br.s $\left(1 \mathrm{H}, \mathrm{H}^{5}\right.$-furan), $8.01 \mathrm{~d}$ $\left(1 \mathrm{H}, \mathrm{H}^{2}\right.$-furan, $\left.{ }^{4} \mathrm{~J}_{\mathrm{HH}}=1.6 \mathrm{~Hz}\right) .{ }^{13} \mathrm{C} \mathrm{NMR}$ spectrum $\left(\mathrm{CDCl}_{3}\right), \delta_{\mathrm{C}}, \mathrm{ppm}: 28.04\left(\mathrm{CH}_{3}\right), 36.73\left(\mathrm{CH}_{2} \mathrm{Cl}\right), 122.59$ ( $\mathrm{C}^{4}$-furan $), 125.41\left(\mathrm{C}^{3}\right.$-furan $), 143.47\left(\mathrm{C}^{5}\right.$-furan $), 149.49$ ( $\mathrm{C}^{2}$-furan), $192.87(\mathrm{C}=\mathrm{O})$.

4-Iodomethyl-3-acetylfuran (12). Chloride 11, $2.14 \mathrm{~g}$, was added to a solution of $5 \mathrm{~g}$ of sodium iodide dihydrate in $25 \mathrm{~mL}$ of acetone at room temperature. The resulting mixture was kept for 24 hours at room temperature in the dark, and then poured in $100 \mathrm{~mL}$ of water, and $5 \mathrm{~g}$ of sodium sulfite and $30 \mathrm{~mL}$ of chloroform were added. The resulting mixture was shaken until discoloration. The organic layer was separated, the aqueous layer was extracted with chloroform $(2 \times 15 \mathrm{~mL})$. The combined extracts were washed with water, with brine, and dried over calcium chloride in the dark. The solution was evaporated, the residue crystallized. Yield $3.13 \mathrm{~g}(93 \%), \mathrm{mp} .54^{\circ} \mathrm{C} .{ }^{1} \mathrm{H}$ NMR spectrum, $\left(\mathrm{CDCl}_{3}\right)$, $\delta$, ppm: $2.43 \mathrm{~s}\left(3 \mathrm{H}, \mathrm{CH}_{3}\right), 4.50$ br.s $\left(2 \mathrm{H}, \mathrm{CH}_{2} \mathrm{I}\right), 7.52$ br.s (1H, $\mathrm{H}^{5}$-furan), $8.01 \mathrm{~d}\left(1 \mathrm{H}, \mathrm{H}^{2}\right.$-furan, $\left.{ }^{4} \mathrm{~J}_{\mathrm{HH}}=1.6 \mathrm{~Hz}\right) .{ }^{13} \mathrm{C}$ NMR spectrum $\left(\mathrm{CDCl}_{3}\right), \delta_{\mathrm{C}}, \mathrm{ppm}:-7.16\left(\mathrm{CH}_{2} \mathrm{I}\right), 28.33$ $\left(\mathrm{CH}_{3}\right), 123.80$ ( $\mathrm{C}^{4}$-furan $), 124.79\left(\mathrm{C}^{3}\right.$-furan $), 143.58\left(\mathrm{C}^{5}\right.$ furan), $149.66\left(\mathrm{C}^{2}\right.$-furan $), 192.35(\mathrm{C}=\mathrm{O})$.

4-(Diethoxyphosphorylmethyl)-3-acetylfuran (5). A mixture of $3.13 \mathrm{~g}$ of iodide $\mathbf{1 2}$ and $5 \mathrm{~mL}$ of triethyl phosphite was heated with stirring. At $115^{\circ} \mathrm{C}$ the distillation of methyl iodide began, which was completed at $150^{\circ} \mathrm{C}$. The reaction time was 10 minutes. Distillation in a vacuum gave $2.23 \mathrm{~g}(68 \%)$ of phosphonate $\mathbf{5}$, colorless oil, bp $145^{\circ} \mathrm{C}(1 \mathrm{mmHg}) .{ }^{1} \mathrm{H}$ NMR spectrum (acetone- $\left.d_{6}\right), \delta$, ppm: $1.23 \mathrm{t}\left(6 \mathrm{H}, \mathrm{CH}_{3}\right.$-phosphonate, $\left.J_{\mathrm{HH}}=7.2 \mathrm{~Hz}\right), 2.43 \mathrm{~s}\left(3 \mathrm{H}, \mathrm{CH}_{3}-\right.$ ketone $), 3.37 \mathrm{~d}(2 \mathrm{H}$, $\left.\mathrm{CH}_{2} \mathrm{P}, J_{\mathrm{PH}}=20.8 \mathrm{~Hz}\right), 4.03$ d.q $\left(4 \mathrm{H}, \mathrm{CH}_{2} \mathrm{O}, J_{\mathrm{PH}}=15.2 \mathrm{~Hz}\right.$, $\left.J_{\mathrm{HH}}=7.2 \mathrm{~Hz}\right), 7.62$ br.s $\left(1 \mathrm{H}, \mathrm{H}^{5}\right.$-furan $), 8.34$ br.s $\left(1 \mathrm{H}, \mathrm{H}^{2}\right.$ furan). ${ }^{13} \mathrm{C}$ NMR spectrum (acetone- $\left.d_{6}\right), \delta_{\mathrm{C}}, \mathrm{ppm}: 15.81 \mathrm{~d}$ $\left(\mathrm{CH}_{3}\right.$-phosphonate, $\left.{ }^{3} J_{\mathrm{PC}}=5.9 \mathrm{~Hz}\right), 20.28 \mathrm{~d}\left(\mathrm{CH}_{2} \mathrm{P},{ }^{1} J_{\mathrm{PC}}=\right.$ $140.6 \mathrm{~Hz}), 27.74\left(\mathrm{CH}_{3}\right.$-ketone $), 61.43 \mathrm{~d}\left(\mathrm{CH}_{2} \mathrm{O},{ }^{2} J_{\mathrm{PC}}=\right.$ $6.3 \mathrm{~Hz}), 115.09 \mathrm{~d}\left(\mathrm{C}^{4}\right.$-furan, $\left.{ }^{2} J_{\mathrm{PC}}=9.1 \mathrm{~Hz}\right), 125.75 \mathrm{~d}\left(\mathrm{C}^{3}-\right.$ furan, $\left.{ }^{3} J_{\mathrm{PC}}=5.9 \mathrm{~Hz}\right), 143.31 \mathrm{~d}\left(\mathrm{C}^{2}\right.$-furan, $\left.{ }^{3} J_{\mathrm{PC}}=7.8 \mathrm{~Hz}\right)$, $150.04\left(\mathrm{C}^{5}\right.$-furan $), 193.24(\mathrm{C}=\mathrm{O}) .{ }^{31} \mathrm{P}$ NMR spectrum (acetone- $d_{6}$ ), $\delta_{\mathrm{P}}$, ppm: 25.84 .

\section{Bromination of (diethoxyphosphorylmethyl)acetyl-} furans. To a solution of $10 \mathrm{mmol}$ of (diethoxyphosphoryl) acetylfuran 1-6 in a mixture of $30 \mathrm{~mL}$ of chloroform, $4 \mathrm{~mL}$ of acetic acid and 3 drops of a $33 \%$ solution of hydrogen bromide in acetic acid a solution of dioxane dibromide, prepared by dissolving of $10.8 \mathrm{mmol}$ of bromine in a mixture of $2 \mathrm{~mL}$ of dioxane and $10 \mathrm{~mL}$ of chloroform was added dropwise with stirring. The addition was carried out at such a rate that the color of the solution was slightly orange, and the temperature of the reaction mixture remained within the range of $20-22^{\circ} \mathrm{C}$. After the end of the addition of the brominating agent, the reaction mixture was stirred at the same temperature for $2-3 \mathrm{~h}$, washed with ice water $(2 \times 15 \mathrm{~mL}), 15 \mathrm{~mL}$ of saturated sodium bicarbonate solution, $15 \mathrm{~mL}$ of $\mathrm{NaCl}$ solution, and dried over sodium sulfate. After removing of the solvent, the residue was kept in a vacuum $(1 \mathrm{mmHg})$ for $1 \mathrm{~h}$ at room temperature.

5-(Diethoxyphosphorylmethyl)-2-bromoacetylfuran (1a). Yield 94\%, light brown oil. ${ }^{1} \mathrm{H}$ NMR spectrum $\left(\mathrm{CDCl}_{3}\right), \delta$, ppm: $1.26 \mathrm{t}\left(6 \mathrm{H}, \mathrm{CH}_{3}\right.$-phosphonate, $\left.J_{\mathrm{HH}}=7.2 \mathrm{~Hz}\right), 3.29 \mathrm{~d}\left(2 \mathrm{H}, \mathrm{CH}_{2} \mathrm{P}, J_{\mathrm{PH}}=21.6 \mathrm{~Hz}\right)$, 4.07 d.q $\left(4 \mathrm{H}, \mathrm{CH}_{2} \mathrm{O}, J_{\mathrm{PH}}=14.8 \mathrm{~Hz}, J_{\mathrm{HH}}=7.2 \mathrm{~Hz}\right), 4.24 \mathrm{~s}$ $\left(2 \mathrm{H}, \mathrm{CH}_{2} \mathrm{Br}\right), 6.45$ d.d $\left(1 \mathrm{H}, \mathrm{H}^{4}\right.$-furan, $J_{\mathrm{HH}}=3.2 \mathrm{~Hz}, J_{\mathrm{PH}}=$ $3.2 \mathrm{~Hz}), 7.25 \mathrm{~d}\left(1 \mathrm{H}, \mathrm{H}^{3}\right.$-furan, $\left.J_{\mathrm{HH}}=3.2 \mathrm{~Hz}\right) .{ }^{13} \mathrm{C} \mathrm{NMR}$ spectrum $\left(\mathrm{CDCl}_{3}\right), \delta_{\mathrm{C}}, \mathrm{ppm}: 16.36 \mathrm{~d}\left(\mathrm{CH}_{3}\right.$-phosphonate, $\left.{ }^{3} J_{\mathrm{PC}}=5.9 \mathrm{~Hz}\right), 27.25 \mathrm{~d}\left(\mathrm{CH}_{2} \mathrm{P},{ }^{1} J_{\mathrm{PC}}=141.5 \mathrm{~Hz}\right), 29.83$ $\left(\mathrm{CH}_{2} \mathrm{Br}\right), 62.65 \mathrm{~d}\left(\mathrm{CH}_{2} \mathrm{O},{ }^{2} J_{\mathrm{PC}}=6.6 \mathrm{~Hz}\right), 111.69 \mathrm{~d}\left(\mathrm{C}^{4}-\right.$ furan, $\left.{ }^{3} J_{\mathrm{PC}}=6.4 \mathrm{~Hz}\right), 120.82 \mathrm{~d}\left(\mathrm{C}^{3}\right.$-furan, $\left.{ }^{4} J_{\mathrm{PC}}=3.2 \mathrm{~Hz}\right)$, $149.56 \mathrm{~d}\left(\mathrm{C}^{2}\right.$-furan, $\left.{ }^{4} J_{\mathrm{PC}}=3.0 \mathrm{~Hz}\right), 152.42 \mathrm{~d}\left(\mathrm{C}^{5}\right.$-furan, $\left.{ }^{2} J_{\mathrm{PC}}=8.5 \mathrm{~Hz}\right), 193.24(\mathrm{C}=\mathrm{O}) .{ }^{31} \mathrm{P}$ NMR spectrum $\left(\mathrm{CDCl}_{3}\right), \delta_{\mathrm{P}}, \mathrm{ppm}: 20.95$.

4-(Diethoxyphosphorylmethyl)-5-methyl-2bromoacetylfuran (2a). Yield 89\%, light brown oil. ${ }^{1} \mathrm{H}$ NMR spectrum $\left(\mathrm{CDCl}_{3}\right), \delta$, ppm: $1.24-1.34 \mathrm{~m}(6 \mathrm{H}$, $\mathrm{CH}_{3}$-phosphonate), $2.38 \mathrm{~d}\left(3 \mathrm{H}, \mathrm{CH}_{3}, J_{\mathrm{PH}}=2.8 \mathrm{~Hz}\right), 2.88 \mathrm{~d}$ $\left(2 \mathrm{H}, \mathrm{CH}_{2} \mathrm{P}, J_{\mathrm{PH}}=20.4 \mathrm{~Hz}\right), 4.04-4.12 \mathrm{~m}\left(4 \mathrm{H}, \mathrm{CH}_{2} \mathrm{O}\right)$, $4.24 \mathrm{~s}\left(2 \mathrm{H}, \mathrm{CH}_{2} \mathrm{Br}\right), 7.28$ br.s $\left(1 \mathrm{H}, \mathrm{H}^{3}\right.$-furan $) .{ }^{13} \mathrm{C} \mathrm{NMR}$ spectrum $\left(\mathrm{CDCl}_{3}\right), \delta_{\mathrm{C}}$, ppm: $12.34 \mathrm{~d}\left(\mathrm{CH}_{3}\right.$-furan, ${ }^{4} \mathrm{~J}_{\mathrm{PC}}=$ $1.3 \mathrm{~Hz}), 16.46 \mathrm{~d}\left(\mathrm{CH}_{3}\right.$-phosphonate, $\left.{ }^{3} J_{\mathrm{PC}}=5.8 \mathrm{~Hz}\right)$, $23.22 \mathrm{~d}\left(\mathrm{CH}_{2} \mathrm{P},{ }^{1} J_{\mathrm{PC}}=143.6 \mathrm{~Hz}\right), 29.72\left(\mathrm{CH}_{2} \mathrm{Br}\right), 62.31 \mathrm{~d}$ $\left(\mathrm{CH}_{2} \mathrm{O},{ }^{2} J_{\mathrm{PC}}=6.6 \mathrm{~Hz}\right), 113.77 \mathrm{~d}\left(\mathrm{C}^{4}\right.$-furan, $\left.{ }^{2} J_{\mathrm{PC}}=9.3 \mathrm{~Hz}\right)$, $120.37 \mathrm{~d}\left(\mathrm{C}^{3}\right.$-furan, $\left.{ }^{3} J_{\mathrm{PC}}=2.8 \mathrm{~Hz}\right), 147.94\left(\mathrm{C}^{2}\right.$-furan $)$, $156.46 \mathrm{~d}\left(\mathrm{C}^{5}\right.$-furan, $\left.{ }^{3} J_{\mathrm{PC}}=10.3 \mathrm{~Hz}\right), 179.54(\mathrm{C}=\mathrm{O}) .{ }^{31} \mathrm{P}$ NMR spectrum $\left(\mathrm{CDCl}_{3}\right), \delta_{\mathrm{P}}, \mathrm{ppm}$ : 25.31 .

3-(Diethoxyphosphorylmethyl)-2-bromoacetylfuran (3a). Yield 87\%, light brown oil. ${ }^{1} \mathrm{H} \mathrm{NMR}\left(\mathrm{CDCl}_{3}\right)$, $\delta$, ppm: $1.18 \mathrm{t}\left(6 \mathrm{H}, \mathrm{CH}_{3}\right.$-phosphonate, $\left.J_{\mathrm{HH}}=7.2 \mathrm{~Hz}\right), 3.46 \mathrm{~d}$ $\left(2 \mathrm{H}, \mathrm{CH}_{2} \mathrm{P}, J_{\mathrm{PH}}=22.0 \mathrm{~Hz}\right), 3.99$ d.q $\left(4 \mathrm{H}, \mathrm{CH}_{2} \mathrm{O}, J_{\mathrm{PH}}=\right.$ $\left.15.2 \mathrm{~Hz}, J_{\mathrm{HH}}=7.2 \mathrm{~Hz}\right), 4.27 \mathrm{~s}\left(2 \mathrm{H}, \mathrm{CH}_{2} \mathrm{Br}\right), 6.63 \mathrm{br} . \mathrm{s}(1 \mathrm{H}$, $\mathrm{H}^{4}$-furan), 7.45 br.s (1H, $\mathrm{H}^{5}$-furan). ${ }^{13} \mathrm{C}$ NMR spectrum $\left(\mathrm{CDCl}_{3}\right), \delta_{\mathrm{C}}$, ppm: $16.29 \mathrm{~d}\left(\mathrm{CH}_{3}\right.$-phosphonate, ${ }^{3} J_{\mathrm{PC}}=$ $6.1 \mathrm{~Hz}), 23.57 \mathrm{~d}\left(\mathrm{CH}_{2} \mathrm{P},{ }^{1} J_{\mathrm{PC}}=138.5 \mathrm{~Hz}\right), 31.06\left(\mathrm{CH}_{2} \mathrm{Br}\right)$, 
$62.23 \mathrm{~d}\left(\mathrm{CH}_{2} \mathrm{O},{ }^{2} J_{\mathrm{PC}}=6.4 \mathrm{~Hz}\right), 115.88 \mathrm{~d}\left(\mathrm{C}^{4}\right.$-furan, $\left.{ }^{3} J_{\mathrm{PC}}=3.3 \mathrm{~Hz}\right), 127.27 \mathrm{~d}\left(\mathrm{C}^{3}\right.$-furan, $\left.{ }^{2} J_{\mathrm{PC}}=9.9 \mathrm{~Hz}\right), 145.55 \mathrm{~d}$ $\left(\mathrm{C}^{5}\right.$-furan, $\left.{ }^{4} J_{\mathrm{PC}}=2.3 \mathrm{~Hz}\right), 146.27 \mathrm{~d}\left(\mathrm{C}^{2}\right.$-furan, ${ }^{3} J_{\mathrm{PC}}=$ $10.1 \mathrm{~Hz}), 181.79 \mathrm{~d}\left(\mathrm{C}=\mathrm{O},{ }^{4} J_{\mathrm{PC}}=2.2 \mathrm{~Hz}\right) .{ }^{31} \mathrm{P} \mathrm{NMR}$ spectrum $\left(\mathrm{CDCl}_{3}\right), \delta_{\mathrm{P}}$, ppm: 24.26 .

2-(Diethoxyphosphorylmethyl)-3-bromoacetylfuran (4a). Yield 84\%, yellowish brown oil. ${ }^{1} \mathrm{H}$ NMR $\left(\mathrm{CDCl}_{3}\right), \delta$, ppm: $1.23-1.27 \mathrm{~m}\left(6 \mathrm{H}, \mathrm{CH}_{3}\right.$-phosphonate), $3.77 \mathrm{~d}\left(2 \mathrm{H}, \mathrm{CH}_{2} \mathrm{P}, J_{\mathrm{PH}}=22.0 \mathrm{~Hz}\right), 4.07$ d.q $\left(4 \mathrm{H}, \mathrm{CH}_{2} \mathrm{O}\right.$, $\left.J_{\mathrm{PH}}=14.4 \mathrm{~Hz}, J_{\mathrm{HH}}=7.2 \mathrm{~Hz}\right), 4.54 \mathrm{~s}\left(2 \mathrm{H}, \mathrm{CH}_{2} \mathrm{Br}\right)$, 7.10 br.s (1H, $\mathrm{H}^{4}$-furan), 7.63 br.s $\left(1 \mathrm{H}, \mathrm{H}^{5}\right.$-furan). ${ }^{13} \mathrm{C}$ NMR spectrum $\left(\mathrm{CDCl}_{3}\right), \delta_{\mathrm{C}}, \mathrm{ppm}: 15.79 \mathrm{~d}\left(\mathrm{CH}_{3^{-}}\right.$ phosphonate, $\left.{ }^{3} J_{\mathrm{PC}}=5.9 \mathrm{~Hz}\right), 26.37 \mathrm{~d}\left(\mathrm{CH}_{2} \mathrm{P},{ }^{1} J_{\mathrm{PC}}=\right.$ $137.0 \mathrm{~Hz}), 33.88\left(\mathrm{CH}_{2} \mathrm{Br}\right), 61.96 \mathrm{~d}\left(\mathrm{CH}_{2} \mathrm{O},{ }^{2} J_{\mathrm{PC}}=6.6 \mathrm{~Hz}\right)$, $110.67 \mathrm{~d}\left(\mathrm{C}^{4}\right.$-furan, $\left.{ }^{4} J_{\mathrm{PC}}=2.6 \mathrm{~Hz}\right), 119.55 \mathrm{~d}\left(\mathrm{C}^{3}\right.$-furan, $\left.{ }^{3} J_{\mathrm{PC}}=7.6 \mathrm{~Hz}\right), 142.34 \mathrm{~d}\left(\mathrm{C}^{5}\right.$-furan, $\left.{ }^{4} J_{\mathrm{PC}}=2.4 \mathrm{~Hz}\right), 153.77 \mathrm{~d}$ $\left(\mathrm{C}^{2}\right.$-furan, $\left.{ }^{2} J_{\mathrm{PC}}=13.7 \mathrm{~Hz}\right), 186.99\left(\mathrm{C}=\mathrm{O},{ }^{4} J_{\mathrm{PC}}=2.3 \mathrm{~Hz}\right)$. ${ }^{31} \mathrm{P}$ NMR spectrum $\left(\mathrm{CDCl}_{3}\right), \delta_{\mathrm{P}}$, ppm: 20.55 .

4-(Diethoxyphosphorylmethyl)-3-bromoacetylfuran (5a). Yield $84 \%$, light yellow oil. ${ }^{1} \mathrm{H}$ NMR $\left(\mathrm{CDCl}_{3}\right), \delta$, ppm: $1.25 \mathrm{t}\left(6 \mathrm{H}, \mathrm{CH}_{3}\right.$-phoshonate, $J_{\mathrm{HH}}=$ $7.2 \mathrm{~Hz}), 3.37 \mathrm{~d}\left(2 \mathrm{H}, \mathrm{CH}_{2} \mathrm{P}, J_{\mathrm{PH}}=20.8 \mathrm{~Hz}\right), 4.04$ d.q $(4 \mathrm{H}$, $\left.\mathrm{CH}_{2} \mathrm{O}, J_{\mathrm{PH}}=15.2 \mathrm{~Hz}, J_{\mathrm{HH}}=7.2 \mathrm{~Hz}\right), 4.56 \mathrm{~s}\left(2 \mathrm{H}, \mathrm{CH}_{2} \mathrm{Br}\right)$, 7.68 br.d $\left(1 \mathrm{H}, \mathrm{H}^{5}\right.$-furan, $\left.J_{\mathrm{PH}}=3.6 \mathrm{~Hz}\right), 8.58$ br.s $\left(1 \mathrm{H}, \mathrm{H}^{2}-\right.$ furan). ${ }^{13} \mathrm{C}$ NMR spectrum $\left(\mathrm{CDCl}_{3}\right), \delta_{\mathrm{C}}, \mathrm{ppm}: 15.83 \mathrm{~d}$ $\left(\mathrm{CH}_{3}\right.$-phosphonate, $\left.{ }^{3} J_{\mathrm{PC}}=5.8 \mathrm{~Hz}\right), 20.37 \mathrm{~d}\left(\mathrm{CH}_{2} \mathrm{P},{ }^{1} J_{\mathrm{PC}}=\right.$ $140.7 \mathrm{~Hz}), 33.23\left(\mathrm{CH}_{2} \mathrm{Br}\right), 61.60 \mathrm{~d}\left(\mathrm{CH}_{2} \mathrm{O},{ }^{2} J_{\mathrm{PC}}=6.4 \mathrm{~Hz}\right)$, $115.54 \mathrm{~d}\left(\mathrm{C}^{4}\right.$-furan, $\left.{ }^{2} J_{\mathrm{PC}}=9.1 \mathrm{~Hz}\right), 122.84 \mathrm{~d}\left(\mathrm{C}^{3}\right.$-furan, $\left.{ }^{3} J_{\mathrm{PC}}=5.8 \mathrm{~Hz}\right), 143.68 \mathrm{~d}\left(\mathrm{C}^{5}\right.$-furan, $\left.{ }^{3} J_{\mathrm{PC}}=7.9 \mathrm{~Hz}\right), 150.54$ ( $\mathrm{C}^{2}$-furan), $187.07(\mathrm{C}=\mathrm{O}) .{ }^{31} \mathrm{P}$ NMR spectrum $\left(\mathrm{CDCl}_{3}\right)$, $\delta_{\mathrm{P}}$, ppm: 25.39 .

5-(Diethoxyphosphorylmethyl)-3-bromoacetylfuran (6a). Yield $85 \%$, light brown oil. ${ }^{1} \mathrm{H} \mathrm{NMR}\left(\mathrm{CDCl}_{3}\right)$, $\delta$, ppm: $1.25 \mathrm{t}\left(6 \mathrm{H}, \mathrm{CH}_{3}\right.$-phosphonate, $\left.J_{\mathrm{HH}}=7.0 \mathrm{~Hz}\right)$, $3.20 \mathrm{~d}\left(2 \mathrm{H}, \mathrm{CH}_{2} \mathrm{P}, J_{\mathrm{PH}}=20.8 \mathrm{~Hz}\right), 4.06$ d.q $\left(4 \mathrm{H}, \mathrm{CH}_{2} \mathrm{O}\right.$, $\left.J_{\mathrm{PH}}=15.6 \mathrm{~Hz}, J_{\mathrm{HH}}=7.0 \mathrm{~Hz}\right), 4.15 \mathrm{~s}\left(2 \mathrm{H}, \mathrm{CH}_{2} \mathrm{Br}\right)$, 6.59 br.d $\left(1 \mathrm{H}, \mathrm{H}^{4}\right.$-furan, $\left.J_{\mathrm{PH}}=4.0 \mathrm{~Hz}\right), 8.05$ br.s $(1 \mathrm{H}$, $\mathrm{H}^{2}$-furan). ${ }^{13} \mathrm{C} \mathrm{NMR}$ spectrum $\left(\mathrm{CDCl}_{3}\right), \delta_{\mathrm{C}}, \mathrm{ppm}: 16.35 \mathrm{~d}$ $\left(\mathrm{CH}_{3}\right.$-phosphonate, $\left.{ }^{3} J_{\mathrm{PC}}=5.9 \mathrm{~Hz}\right), 26.56 \mathrm{~d}\left(\mathrm{CH}_{2} \mathrm{P},{ }^{1} J_{\mathrm{PC}}=\right.$ $142.9 \mathrm{~Hz}), 31.57\left(\mathrm{CH}_{2} \mathrm{Br}\right), 62.15 \mathrm{~d}\left(\mathrm{CH}_{2} \mathrm{O},{ }^{2} J_{\mathrm{PC}}=\right.$ $6.6 \mathrm{~Hz}), 107.18 \mathrm{~d}\left(\mathrm{C}^{4}\right.$-furan, $\left.{ }^{3} J_{\mathrm{PC}}=7.3 \mathrm{~Hz}\right), 125.70 \mathrm{~d}$ $\left(\mathrm{C}^{3}\right.$-furan, $\left.{ }^{4} J_{\mathrm{PC}}=2.7 \mathrm{~Hz}\right), 147.74 \mathrm{~d}\left(\mathrm{C}^{2}\right.$-furan, ${ }^{4} J_{\mathrm{PC}}=$ $2.3 \mathrm{~Hz}), 148.63 \mathrm{~d}\left(\mathrm{C}^{5}\right.$-furan, $\left.{ }^{2} J_{\mathrm{PC}}=9.3 \mathrm{~Hz}\right), 185.89$ $(\mathrm{C}=\mathrm{O}) .{ }^{31} \mathrm{P}$ NMR spectrum $\left(\mathrm{CDCl}_{3}\right), \delta_{\mathrm{P}}, \mathrm{ppm}: 21.76$.

2-(Diethoxyphosphorylmethyl)-3-dibromoacetylfuran (13). It was obtained analogously from $3.26 \mathrm{~g}$ (9.6 mmol) of bromoacetylfuran 4a. Yield $2.79 \mathrm{~g}(69 \%)$, reddish brown oil. ${ }^{1} \mathrm{H} \mathrm{NMR}\left(\mathrm{CDCl}_{3}\right), \delta$, ppm: $1.22 \mathrm{t}(6 \mathrm{H}$, $\mathrm{CH}_{3}$-phosphonate, $\left.J_{\mathrm{HH}}=7.2 \mathrm{~Hz}\right), 3.73 \mathrm{~d}\left(2 \mathrm{H}, \mathrm{CH}_{2} \mathrm{P}, J_{\mathrm{PH}}=\right.$
$22.4 \mathrm{~Hz}), 4.04$ d.q $\left(4 \mathrm{H}, \mathrm{CH}_{2} \mathrm{O}, J_{\mathrm{PH}}=14.8 \mathrm{~Hz}, J_{\mathrm{HH}}=\right.$ $7.2 \mathrm{~Hz}), 6.26 \mathrm{~s}\left(1 \mathrm{H}, \mathrm{CHBr}_{2}\right), 6.86 \mathrm{~d}\left(1 \mathrm{H}, \mathrm{H}^{4}\right.$-furan, $J_{\mathrm{HH}}=$ $1.6 \mathrm{~Hz}), 7.37$ d.d $\left(1 \mathrm{H}, \mathrm{H}^{5}\right.$-furan, $J_{\mathrm{HH}}=1.6 \mathrm{~Hz}, J_{\mathrm{PH}}=$ $1.6 \mathrm{~Hz}) .{ }^{13} \mathrm{C}$ NMR spectrum $\left(\mathrm{CDCl}_{3}\right), \delta_{\mathrm{C}}, \mathrm{ppm}: 16.29 \mathrm{~d}$ $\left(\mathrm{CH}_{3}\right.$-phosphonate, $\left.{ }^{3} \mathrm{~J}_{\mathrm{PC}}=6.1 \mathrm{~Hz}\right), 27.01 \mathrm{~d}\left(\mathrm{CH}_{2} \mathrm{P},{ }^{1} J_{\mathrm{PC}}=\right.$ $137.4 \mathrm{~Hz}), 41.52\left(\mathrm{CHBr}_{2}\right), 62.58 \mathrm{~d}\left(\mathrm{CH}_{2} \mathrm{O},{ }^{2} J_{\mathrm{PC}}=6.2 \mathrm{~Hz}\right)$, $110.46 \mathrm{~d}\left(\mathrm{C}^{4}\right.$-furan, $\left.{ }^{4} J_{\mathrm{PC}}=2.3 \mathrm{~Hz}\right), 115.98 \mathrm{~d}\left(\mathrm{C}^{3}\right.$-furan, $\left.{ }^{3} J_{\mathrm{PC}}=7.7 \mathrm{~Hz}\right), 141.95 \mathrm{~d}\left(\mathrm{C}^{5}\right.$-furan, $\left.{ }^{4} J_{\mathrm{PC}}=2.1 \mathrm{~Hz}\right), 156.43 \mathrm{~d}$ $\left(\mathrm{C}^{2}\right.$-furan, $\left.{ }^{2} J_{\mathrm{PC}}=13.7 \mathrm{~Hz}\right), 181.76 \mathrm{~d}\left(\mathrm{C}=\mathrm{O},{ }^{4} J_{\mathrm{PC}}=2.3 \mathrm{~Hz}\right)$. ${ }^{31} \mathrm{P}$ NMR spectrum $\left(\mathrm{CDCl}_{3}\right), \delta_{\mathrm{P}}, \mathrm{ppm}: 20.54$.

Alkylation of $\mathrm{CH}$-acids with bromoacetylfurans 1a-6a. Freshly prepared sodium foil, $5.25 \mathrm{mg}$-eq, was dissolved in a mixture of $1 \mathrm{~mL}$ of absolute ethanol and $10 \mathrm{~mL}$ of anhydrous dioxane. After the formation of a homogeneous solution, $5.50 \mathrm{mmol}$ of the alkylated substrate was added and stirred for $20 \mathrm{~min}$, then $5.00 \mathrm{mmol}$ of bromoacetylfuran was added in one portion and the resulting mixture was heated for $10 \mathrm{~h}$ at $90^{\circ} \mathrm{C}$ with vigorous stirring. After the completion of the reaction, the solvents were distilled off, the residue was dissolved in $30 \mathrm{~mL}$ of chloroform, washed with $10 \mathrm{~mL}$ of water, $10 \mathrm{~mL}$ of $\mathrm{NaCl}$ solution, and dried over sodium sulfate. After removing the solvent, the residue was kept in a vacuum $(1 \mathrm{mmHg})$ for $1 \mathrm{~h}$ at room temperature.

Ethyl 2-acetyl-4-[5-(diethoxyphosphorylmethyl)fur-2-yl)]-4-oxobutanoate (1b). Yield 61\%, light red oil. ${ }^{1} \mathrm{H}$ NMR spectrum $\left(\mathrm{CDCl}_{3}\right), \delta$, ppm: $1.23-1.31 \mathrm{~m}(9 \mathrm{H}$, $\mathrm{CH}_{3}$-ester, $\mathrm{CH}_{3}$-phosphonate), $2.25 \mathrm{~s}\left(3 \mathrm{H}, \mathrm{CH}_{3}\right.$-acetyl), $3.29 \mathrm{~d}\left(2 \mathrm{H}, \mathrm{CH}_{2} \mathrm{P}, J_{\mathrm{PH}}=20.8 \mathrm{~Hz}\right), 3.30$ d.d $\left(1 \mathrm{H}, \mathrm{CH}_{2}, \mathrm{H}_{\mathrm{A}}\right.$, $\left.J_{\mathrm{AB}}=18.0 \mathrm{~Hz}, J_{\mathrm{AH}}=3.0 \mathrm{~Hz}\right), 3.49$ d.d $\left(1 \mathrm{H}, \mathrm{CH}_{2}, \mathrm{H}_{\mathrm{B}}, J_{\mathrm{AB}}=\right.$ $\left.18.0 \mathrm{~Hz}, J_{\mathrm{AH}}=8.2 \mathrm{~Hz}\right), 4.10$ d.q $\left(4 \mathrm{H}, \mathrm{CH}_{2} \mathrm{O}\right.$-phosphonate, $\left.J_{\mathrm{PH}}=14.8 \mathrm{~Hz}, J_{\mathrm{HH}}=7.2 \mathrm{~Hz}\right), 4.18 \mathrm{q}\left(2 \mathrm{H}, \mathrm{CH}_{2} \mathrm{O}\right.$-ester, $\left.J_{\mathrm{HH}}=7.2 \mathrm{~Hz}\right), 6.43$ d.d $\left(1 \mathrm{H}, \mathrm{H}^{4}\right.$-furan, $J_{\mathrm{PH}}=3.2 \mathrm{~Hz}, J_{\mathrm{HH}}=$ $3.2 \mathrm{~Hz}), 7.17 \mathrm{~d}\left(1 \mathrm{H}, \mathrm{H}^{3}\right.$-furan, $\left.J_{\mathrm{HH}}=3.2 \mathrm{~Hz}\right) .{ }^{13} \mathrm{C} \mathrm{NMR}$ spectrum $\left(\mathrm{CDCl}_{3}\right), \delta_{\mathrm{C}}$, ppm: $14.06\left(\mathrm{CH}_{3}\right.$-ester $), 16.33 \mathrm{~d}$ $\left(\mathrm{CH}_{3}\right.$-phosphonate, $\left.{ }^{3} J_{\mathrm{PC}}=5.9 \mathrm{~Hz}\right), 27.13 \mathrm{~d}\left(\mathrm{CH}_{2} \mathrm{P}\right.$, $\left.{ }^{1} J_{\mathrm{PC}}=141.7 \mathrm{~Hz}\right), 30.10\left(\mathrm{CH}_{3}\right.$-acetyl $), 36.57\left(\mathrm{CH}_{2} \mathrm{CO}\right)$, $53.37(\mathrm{CH}), 61.33\left(\mathrm{CH}_{2} \mathrm{O}\right.$-ester $), 62.62 \mathrm{~d}\left(\mathrm{CH}_{2} \mathrm{O}-\right.$ phosphonate, $\left.{ }^{2} J_{\mathrm{PC}}=6.0 \mathrm{~Hz}\right), 62.67 \mathrm{~d}\left(\mathrm{CH}_{2} \mathrm{O}\right.$-phosphonate, $\left.{ }^{2} J_{\mathrm{PC}}=6.1 \mathrm{~Hz}\right), 111.19 \mathrm{~d}\left(\mathrm{C}^{4}\right.$-furan, $\left.{ }^{3} J_{\mathrm{PC}}=6.4 \mathrm{~Hz}\right), 120.80 \mathrm{~d}$ $\left(\mathrm{C}^{3}\right.$-furan, $\left.{ }^{4} J_{\mathrm{PC}}=3.2 \mathrm{~Hz}\right), 151.32 \mathrm{~d}\left(\mathrm{C}^{2}\right.$-furan, $\left.{ }^{4} J_{\mathrm{PC}}=2.8 \mathrm{~Hz}\right)$, $151.44 \mathrm{~d}\left(\mathrm{C}^{5}\right.$-furan, $\left.{ }^{2} J_{\mathrm{PC}}=8.4 \mathrm{~Hz}\right), 168.68(\mathrm{C}=\mathrm{O}$-ester $)$, $185.36(\mathrm{C}=\mathrm{O}$-furan $), 202.07\left(\mathrm{C}=\mathrm{O}\right.$-acetyl). ${ }^{31} \mathrm{P} \mathrm{NMR}$ spectrum $\left(\mathrm{CDCl}_{3}\right), \delta_{\mathrm{P}}$, ppm: 21.30 .

Ethyl 2-acetyl-4-[5-methyl-4-(diethoxyphosphorylmethyl)fur-2-yl)]-4-oxobutanoate (2b). Yield $54 \%$, light brown oil. ${ }^{1} \mathrm{H}$ NMR spectrum $\left(\mathrm{CDCl}_{3}\right), \delta$, ppm: 1.23-1.33 m (9H, $\mathrm{CH}_{3}$-ester, $\mathrm{CH}_{3}$-phosphonate), $2.23 \mathrm{~d}$ $\left(3 \mathrm{H}, \mathrm{CH}_{3}, J_{\mathrm{PH}}=2.8 \mathrm{~Hz}\right), 2.38 \mathrm{~s}\left(3 \mathrm{H}, \mathrm{CH}_{3}\right.$-acetyl $), 2.86 \mathrm{~d}$ 
$\left(2 \mathrm{H}, \mathrm{CH}_{2} \mathrm{P}, J_{\mathrm{PH}}=20.4 \mathrm{~Hz}\right), 3.23$ d.d $\left(1 \mathrm{H}, \mathrm{CH}_{2}, \mathrm{H}_{\mathrm{A}}, J_{\mathrm{AB}}=\right.$ $\left.18.2 \mathrm{~Hz}, J_{\mathrm{AH}}=5.8 \mathrm{~Hz}\right), 3.29$ d.d $\left(1 \mathrm{H}, \mathrm{CH}_{2}, \mathrm{H}_{\mathrm{B}}, J_{\mathrm{AB}}=\right.$ $\left.18.0 \mathrm{~Hz}, J_{\mathrm{AH}}=8.0 \mathrm{~Hz}\right), 4.02-4.12 \mathrm{~m}\left(4 \mathrm{H}, \mathrm{CH}_{2} \mathrm{O}-\right.$ phosphonate), $4.18 \mathrm{q}\left(2 \mathrm{H}, \mathrm{CH}_{2} \mathrm{O}\right.$-ester, $\left.J_{\mathrm{HH}}=7.2 \mathrm{~Hz}\right)$, $7.16 \mathrm{~s}\left(1 \mathrm{H}, \mathrm{H}^{3}\right.$-furan $) .{ }^{13} \mathrm{C} \mathrm{NMR}$ spectrum $\left(\mathrm{CDCl}_{3}\right), \delta_{\mathrm{C}}$, ppm: $12.17 \mathrm{~d}\left(\mathrm{CH}_{3}\right.$-furan, $\left.{ }^{4} J_{\mathrm{PC}}=1.5 \mathrm{~Hz}\right), 14.01\left(\mathrm{CH}_{3}-\right.$ ester), $16.43 \mathrm{~d}\left(\mathrm{CH}_{3}\right.$-phosphonate, $\left.{ }^{3} J_{\mathrm{PC}}=5.8 \mathrm{~Hz}\right), 23.19 \mathrm{~d}$ $\left(\mathrm{CH}_{2} \mathrm{P},{ }^{1} J_{\mathrm{PC}}=143.4 \mathrm{~Hz}\right), 29.66\left(\mathrm{CH}_{3}\right.$-acetyl $), 36.42$ $\left(\mathrm{CH}_{2} \mathrm{CO}\right), 53.41(\mathrm{CH}), 61.71\left(\mathrm{CH}_{2} \mathrm{O}\right.$-ester $), 62.30 \mathrm{~d}$ $\left(\mathrm{CH}_{2} \mathrm{O}\right.$-phosphonate, $\left.{ }^{2} J_{\mathrm{PC}}=6.7 \mathrm{~Hz}\right), 62.33 \mathrm{~d}\left(\mathrm{CH}_{2} \mathrm{O}-\right.$ phosphonate, $\left.{ }^{2} J_{\mathrm{PC}}=6.6 \mathrm{~Hz}\right), 113.09 \mathrm{~d}\left(\mathrm{C}^{4}\right.$-furan, $\left.{ }^{2} J_{\mathrm{PC}}=9.2 \mathrm{~Hz}\right), 120.65 \mathrm{~d}\left(\mathrm{C}^{3}\right.$-furan, $\left.{ }^{3} J_{\mathrm{PC}}=2.0 \mathrm{~Hz}\right), 149.65$ ( $\mathrm{C}^{2}$-furan), $155.34 \mathrm{~d}\left(\mathrm{C}^{5}\right.$-furan, $\left.{ }^{3} J_{\mathrm{PC}}=10.1 \mathrm{~Hz}\right), 168.76$ (C=O-ester), 185.21 (C=O-furan), $200.65(\mathrm{C}=\mathrm{O}$-acetyl). ${ }^{31} \mathrm{P}$ NMR spectrum $\left(\mathrm{CDCl}_{3}\right), \delta_{\mathrm{P}}, \mathrm{ppm}: 25.51$.

Ethyl 2-acetyl-4-[3-(diethoxyphosphorylmethyl)fur-2-yl)]-4-oxobutanoate (3b). Yield 50\%, yellowish brown oil. ${ }^{1} \mathrm{HNMR}$ spectrum $\left(\mathrm{CDCl}_{3}\right), \delta$, ppm: $1.17-1.22 \mathrm{~m}$ (9H, $\mathrm{CH}_{3}$-ester, $\mathrm{CH}_{3}$-phosphonate), $2.19 \mathrm{~s}\left(3 \mathrm{H}, \mathrm{CH}_{3}\right.$ acetyl), 3.34 d.d $\left(1 \mathrm{H}, \mathrm{CH}_{2}, \mathrm{H}_{\mathrm{A}}, J_{\mathrm{AB}}=18.6 \mathrm{~Hz}, J_{\mathrm{AH}}=\right.$ $6.0 \mathrm{~Hz}), 3.47 \mathrm{~d} . \mathrm{d}\left(1 \mathrm{H}, \mathrm{CH}_{2} \mathrm{P}, \mathrm{H}_{\mathrm{A}}, J_{\mathrm{AB}}=14.8 \mathrm{~Hz}, J_{\mathrm{AP}}=\right.$ $20.8 \mathrm{~Hz}), 3.51$ d.d $\left(1 \mathrm{H}, \mathrm{CH}_{2} \mathrm{P}, \mathrm{H}_{\mathrm{B}}, J_{\mathrm{AB}}=14.8 \mathrm{~Hz}, J_{\mathrm{BP}}\right.$ $=20.8 \mathrm{~Hz}), 3.52 \mathrm{~d} . \mathrm{d}\left(1 \mathrm{H}, \mathrm{CH}_{2}, \mathrm{H}_{\mathrm{B}}, J_{\mathrm{AB}}=18.6 \mathrm{~Hz}, J_{\mathrm{AH}}\right.$ $=8.4 \mathrm{~Hz}), 3.95-4.06 \mathrm{~m}\left(4 \mathrm{H}, \mathrm{CH}_{2} \mathrm{O}-\right.$ phosphonate $), 4.12$ q $\left(2 \mathrm{H}, \mathrm{CH}_{2} \mathrm{O}\right.$-ester, $\left.J_{\mathrm{HH}}=7.0 \mathrm{~Hz}\right), 6.71$ br.s $\left(1 \mathrm{H}, \mathrm{H}^{3}-\right.$ furan), 7.42 br.s $\left(1 \mathrm{H}, \mathrm{H}^{4}\right.$-furan). ${ }^{13} \mathrm{C}$ NMR spectrum $\left(\mathrm{CDCl}_{3}\right), \delta_{\mathrm{C}}, \mathrm{ppm}: 14.01\left(\mathrm{CH}_{3}\right.$-ester $), 16.23 \mathrm{~d}\left(\mathrm{CH}_{3^{-}}\right.$ phosphonate, $\left.{ }^{3} J_{\mathrm{PC}}=5.9 \mathrm{~Hz}\right), 23.41 \mathrm{~d}\left(\mathrm{CH}_{2} \mathrm{P},{ }^{1} J_{\mathrm{PC}}=138.0\right.$ $\mathrm{Hz}), 30.06\left(\mathrm{CH}_{3}\right.$-acetyl), $37.47\left(\underline{\mathrm{CH}}_{2} \mathrm{CO}\right), 53.15(\mathrm{CH})$, $61.25\left(\mathrm{CH}_{2} \mathrm{O}\right.$-ester $), 62.11 \mathrm{~d}\left(\mathrm{CH}_{2} \mathrm{O}\right.$-phosphonate, ${ }^{2} J_{\mathrm{PC}}=$ $6.4 \mathrm{~Hz}), 62.23 \mathrm{~d}\left(\mathrm{CH}_{2} \mathrm{O}\right.$-phosphonate, $\left.{ }^{2} J_{\mathrm{PC}}=6.5 \mathrm{~Hz}\right)$, $115.35 \mathrm{~d}\left(\mathrm{C}^{4}\right.$-furan, $\left.{ }^{3} J_{\mathrm{PC}}=3.5 \mathrm{~Hz}\right), 124.94 \mathrm{~d}\left(\mathrm{C}^{3}\right.$-furan, $\left.{ }^{2} J_{\mathrm{PC}}=9.6 \mathrm{~Hz}\right), 144.94 \mathrm{~d}\left(\mathrm{C}^{5}\right.$-furan, $\left.{ }^{4} J_{\mathrm{PC}}=2.0 \mathrm{~Hz}\right), 147.78 \mathrm{~d}$ $\left(\mathrm{C}^{2}\right.$-furan, $\left.{ }^{3} J_{\mathrm{PC}}=10.4 \mathrm{~Hz}\right), 167.06(\mathrm{C}=\mathrm{O}$-ester $), 187.88 \mathrm{~d}$ $\left(\mathrm{C}=\mathrm{O}\right.$-furan, $\left.{ }^{4} J_{\mathrm{PC}}=1.9 \mathrm{~Hz}\right), 200.62(\mathrm{C}=\mathrm{O}$-acetyl $) .{ }^{31} \mathrm{P}$ NMR spectrum $\left(\mathrm{CDCl}_{3}\right), \delta_{\mathrm{P}}$, ppm: 24.80 .

Ethyl 2-acetyl-4-[2-(diethoxyphosphorylmethyl)fur-3-yl)]-4-oxobutanoate (4b). Yield 49\%, yellowish brown oil. ${ }^{1} \mathrm{HNMR}$ spectrum $\left(\mathrm{CDCl}_{3}\right), \delta$, ppm: $1.21-1.26 \mathrm{~m}$ (9H, $\mathrm{CH}_{3}$-ester, $\mathrm{CH}_{3}$-phosphonate), $2.23 \mathrm{~s}\left(3 \mathrm{H}, \mathrm{CH}_{3}\right.$ acetyl), 3.29 d.d $\left(1 \mathrm{H}, \mathrm{CH}_{2}, \mathrm{H}_{\mathrm{A}}, J_{\mathrm{AB}}=18.8 \mathrm{~Hz}, J_{\mathrm{AH}}=\right.$ $4.6 \mathrm{~Hz}), 3.43$ d.d $\left(1 \mathrm{H}, \mathrm{CH}_{2}, \mathrm{H}_{\mathrm{B}}, J_{\mathrm{AB}}=18.8 \mathrm{~Hz}, J_{\mathrm{AH}}=\right.$ $8.4 \mathrm{~Hz}), 3.75 \mathrm{~d}\left(2 \mathrm{H}, \mathrm{CH}_{2} \mathrm{P}, J_{\mathrm{PH}}=22.4 \mathrm{~Hz}\right), 4.00-4.11 \mathrm{~m}$ (4H, $\mathrm{CH}_{2} \mathrm{O}$-phosphonate), $4.16 \mathrm{q}\left(2 \mathrm{H}, \mathrm{CH}_{2} \mathrm{O}\right.$-ester, $\left.J_{\mathrm{HH}}=7.0 \mathrm{~Hz}\right), 6.71$ br.s $\left(1 \mathrm{H}, \mathrm{H}^{3}\right.$-furan $), 7.33$ br.s $(1 \mathrm{H}$, $\mathrm{H}^{4}$-furan). ${ }^{13} \mathrm{C} \mathrm{NMR}$ spectrum $\left(\mathrm{CDCl}_{3}\right), \delta_{\mathrm{C}}, \mathrm{ppm}: 14.04$ ( $\mathrm{CH}_{3}$-ester), 16.24 br.d $\left(\mathrm{CH}_{3}\right.$-phosphonate, $\left.{ }^{3} \mathrm{~J}_{\mathrm{PC}}=5.0 \mathrm{~Hz}\right)$, $26.61 \mathrm{~d}\left(\mathrm{CH}_{2} \mathrm{P},{ }^{1} J_{\mathrm{PC}}=138.3 \mathrm{~Hz}\right), 30.17\left(\mathrm{CH}_{3}\right.$-acetyl $)$, $39.51\left(\mathrm{CH}_{2} \mathrm{CO}\right), 53.36(\mathrm{CH}), 61.72\left(\mathrm{CH}_{2} \mathrm{O}\right.$-ester $), 62.43 \mathrm{~d}$
$\left(\mathrm{CH}_{2} \mathrm{O}\right.$-phosphonate, $\left.{ }^{2} J_{\mathrm{PC}}=6.3 \mathrm{~Hz}\right), 62.60 \mathrm{~d}\left(\mathrm{CH}_{2} \mathrm{O}-\right.$ phosphonate, $\left.{ }^{2} J_{\mathrm{PC}}=6.2 \mathrm{~Hz}\right), 110.03 \mathrm{~d}\left(\mathrm{C}^{4}\right.$-furan, ${ }^{4} J_{\mathrm{PC}}=$ $2.2 \mathrm{~Hz}), 121.26 \mathrm{~d}\left(\mathrm{C}^{3}\right.$-furan, $\left.{ }^{3} J_{\mathrm{PC}}=9.6 \mathrm{~Hz}\right), 142.92 \mathrm{~d}\left(\mathrm{C}^{5}\right.$ furan, $\left.{ }^{4} J_{\mathrm{PC}}=2.6 \mathrm{~Hz}\right), 152.10 \mathrm{~d}\left(\mathrm{C}^{2}\right.$-furan, $\left.{ }^{2} J_{\mathrm{PC}}=13.7 \mathrm{~Hz}\right)$, 168.26 (C=O-ester), $192.71 \mathrm{~d}\left(\mathrm{C}=\mathrm{O}-\right.$ furan, $\left.{ }^{4} \mathrm{~J}_{\mathrm{PC}}=2.4 \mathrm{~Hz}\right)$, $202.18(\mathrm{C}=\mathrm{O}$-acetyl $) .{ }^{31} \mathrm{P}$ NMR spectrum $\left(\mathrm{CDCl}_{3}\right), \delta_{\mathrm{P}}$, ppm: 21.43 .

Ethyl 2-acetyl-4-[4-(diethoxyphosphorylmethyl)fur-3-yl)]-4-oxobutanoate (5b). Yield 72\%, yellow oil. ${ }^{1} \mathrm{H}$ NMR spectrum (acetone- $d_{6}$ ), $\delta$, ppm: $1.22-1.30 \mathrm{~m}$ (9H, $\mathrm{CH}_{3}$-ester, $\mathrm{CH}_{3}$-phosphonate), $2.35 \mathrm{~s}\left(3 \mathrm{H}, \mathrm{CH}_{3}\right.$ acetyl), $3.34 \mathrm{~d}\left(2 \mathrm{H}, \mathrm{CH}_{2} \mathrm{P}, J_{\mathrm{PH}}=21.2 \mathrm{~Hz}\right), 3.38 \mathrm{~d} . \mathrm{d}(1 \mathrm{H}$, $\left.\mathrm{CH}_{2}, \mathrm{H}_{\mathrm{A}}, J_{\mathrm{AB}}=18.2 \mathrm{~Hz}, J_{\mathrm{AH}}=6.4 \mathrm{~Hz}\right), 3.47$ d.d $\left(1 \mathrm{H}, \mathrm{CH}_{2}\right.$, $\left.\mathrm{H}_{\mathrm{B}}, J_{\mathrm{AB}}=18.2 \mathrm{~Hz}, J_{\mathrm{AH}}=7.4 \mathrm{~Hz}\right), 4.02$ d.q $\left(4 \mathrm{H}, \mathrm{CH}_{2} \mathrm{O}-\right.$ phosphonate, $\left.J_{\mathrm{PH}}=14.8 \mathrm{~Hz}, J_{\mathrm{HH}}=7.2 \mathrm{~Hz}\right), 4.14-4.19 \mathrm{~m}$ ( $3 \mathrm{H}, \mathrm{CH}_{2} \mathrm{O}$-ester, $\left.\mathrm{CH}\right), 7.64$ br.s $\left(1 \mathrm{H}, \mathrm{H}^{5}\right.$-furan), $8.57 \mathrm{~s}$ $\left(1 \mathrm{H}, \mathrm{H}^{2}\right.$-furan). ${ }^{13} \mathrm{C}$ NMR spectrum (acetone- $\left.d_{6}\right), \delta_{\mathrm{C}}$, ppm: $13.46\left(\mathrm{CH}_{3}\right.$-ester $), 15.82$ br.d $\left(\mathrm{CH}_{3}\right.$-phosphonate, ${ }^{3} J_{\mathrm{PC}}=$ $5.8 \mathrm{~Hz}), 20.36 \mathrm{~d}\left(\mathrm{CH}_{2} \mathrm{P},{ }^{1} J_{\mathrm{PC}}=140.6 \mathrm{~Hz}\right), 38.69\left(\underline{\mathrm{CH}}_{2} \mathrm{CO}\right)$, $53.47(\mathrm{CH}), 61.08\left(\mathrm{CH}_{2} \mathrm{O}\right.$-ester $), 61.48 \mathrm{~d}\left(\mathrm{CH}_{2} \mathrm{O}-\right.$ phosphonate, $\left.{ }^{2} J_{\mathrm{PC}}=6.4 \mathrm{~Hz}\right), 115.10 \mathrm{~d}\left(\mathrm{C}^{4}\right.$-furan, ${ }^{2} J_{\mathrm{PC}}=$ $8.9 \mathrm{~Hz}), 124.83 \mathrm{~d}\left(\mathrm{C}^{3}\right.$-furan, $\left.{ }^{3} J_{\mathrm{PC}}=5.8 \mathrm{~Hz}\right), 143.37 \mathrm{~d}$ $\left(\mathrm{C}^{5}\right.$-furan, $\left.{ }^{3} J_{\mathrm{PC}}=7.7 \mathrm{~Hz}\right), 149.97\left(\mathrm{C}^{2}\right.$-furan $), 168.76$ (C=O-ester), $193.06(\mathrm{C}=\mathrm{O}$-furan $), 201.74(\mathrm{C}=\mathrm{O}$-acetyl). ${ }^{31} \mathrm{P}$ NMR spectrum (acetone- $d_{6}$ ), $\delta_{\mathrm{P}}, \mathrm{ppm}: 25.65$.

Ethyl 2-acetyl-4-[5-(diethoxyphosphorylmethyl)fur-3-yl)]-4-oxobutanoate (6b). Yield 69\%, light brown oil. ${ }^{1} \mathrm{H}$ NMR spectrum $\left(\mathrm{CDCl}_{3}\right), \delta$, ppm: common signals: $1.24-1.32 \mathrm{~m}\left(9 \mathrm{H}, \mathrm{CH}_{3}\right.$-ester, $\mathrm{CH}_{3}$-phosphonate), 4.06-4.14 m (4H, $\mathrm{CH}_{2} \mathrm{O}$-phosphonate), 4.16-4.23 m $\left(3 \mathrm{H}, \mathrm{CH}_{2} \mathrm{O}\right.$-ester, $\left.\mathrm{CH}\right)$; main conformer: $2.26 \mathrm{~s}(3 \mathrm{H}$, $\mathrm{CH}_{3}$-acetyl $), 3.22 \mathrm{~d}\left(2 \mathrm{H}, \mathrm{CH}_{2} \mathrm{P}, J_{\mathrm{PH}}=20.8 \mathrm{~Hz}\right), 3.25 \mathrm{~d} . \mathrm{d}$ $\left(1 \mathrm{H}, \mathrm{CH}_{2}, \mathrm{H}_{\mathrm{A}}, J_{\mathrm{AB}}=18.0 \mathrm{~Hz}, J_{\mathrm{AH}}=6.0 \mathrm{~Hz}\right), 3.43 \mathrm{~d} . \mathrm{d}$ $\left(1 \mathrm{H}, \mathrm{CH}_{2}, \mathrm{H}_{\mathrm{B}}, J_{\mathrm{AB}}=18.0 \mathrm{~Hz}, J_{\mathrm{AH}}=8.4 \mathrm{~Hz}\right), 6.58 \mathrm{~s}(1 \mathrm{H}$, $\mathrm{H}^{4}$-furan), $8.01 \mathrm{~s}\left(1 \mathrm{H}, \mathrm{H}^{2}\right.$-furan); minor isomer: $2.40 \mathrm{~s}$ ( $3 \mathrm{H}, \mathrm{CH}_{3}$-acetyl), $3.24 \mathrm{~d}\left(2 \mathrm{H}, \mathrm{CH}_{2} \mathrm{P}, J_{\mathrm{PH}}=20.8 \mathrm{~Hz}\right)$, 3.24 d.d $\left(1 \mathrm{H}, \mathrm{CH}_{2}, \mathrm{H}_{\mathrm{A}}, J_{\mathrm{AB}}=18.0 \mathrm{~Hz}, J_{\mathrm{AH}}=6.0 \mathrm{~Hz}\right)$, 3.44 d.d $\left(1 \mathrm{H}, \mathrm{CH}_{2}, \mathrm{H}_{\mathrm{B}}, J_{\mathrm{AB}}=18.0 \mathrm{~Hz}, J_{\mathrm{AH}}=8.4 \mathrm{~Hz}\right)$, $6.63 \mathrm{~s}\left(1 \mathrm{H}, \mathrm{H}^{4}\right.$-furan $), 8.04 \mathrm{~s}\left(1 \mathrm{H}, \mathrm{H}^{2}\right.$-furan $)$. Isomer ratio $1: 0.5 .{ }^{13} \mathrm{C}$ NMR spectrum $\left(\mathrm{CDCl}_{3}\right), \delta_{\mathrm{C}}, \mathrm{ppm}$ : common signals: $16.37 \mathrm{~d}\left(\mathrm{CH}_{3}\right.$-phosphonate, $\left.{ }^{3} J_{\mathrm{PC}}=5.9 \mathrm{~Hz}\right), 53.44$ (CH), 62.50 br.d $\left(\mathrm{CH}_{2} \mathrm{O}\right.$-phosphonate, $\left.{ }^{2} J_{\mathrm{PC}}=6.5 \mathrm{~Hz}\right)$, $127.90 \mathrm{~d}\left(\mathrm{C}^{3}\right.$-furan, $\left.{ }^{4} J_{\mathrm{PC}}=2.7 \mathrm{~Hz}\right), 146.89 \mathrm{~d}\left(\mathrm{C}^{2}\right.$-furan, $\left.{ }^{4} J_{\mathrm{PC}}=2.2 \mathrm{~Hz}\right), 148.29 \mathrm{~d}\left(\mathrm{C}^{5}\right.$-furan, $\left.{ }^{2} J_{\mathrm{PC}}=9.4 \mathrm{~Hz}\right)$; main isomer: $14.07\left(\mathrm{CH}_{3}\right.$-ester $), 26.61 \mathrm{~d}\left(\mathrm{CH}_{2} \mathrm{P},{ }^{1} J_{\mathrm{PC}}=\right.$ $142.9 \mathrm{~Hz}), 30.11\left(\mathrm{CH}_{3}\right.$-acetyl), $38.36\left(\underline{\mathrm{CH}}_{2} \mathrm{CO}\right), 61.35$ $\left(\mathrm{CH}_{2} \mathrm{O}\right.$-ester $), 106.76 \mathrm{~d}\left(\mathrm{C}^{4}\right.$-furan, $\left.{ }^{3} J_{\mathrm{PC}}=7.3 \mathrm{~Hz}\right), 167.71$ (C=O-ester), 191.59 (C=O-furan), $200.64(\mathrm{C}=\mathrm{O}$-acetyl); minor isomer: $14.01\left(\mathrm{CH}_{3}\right.$-ester $), 26.57 \mathrm{~d}\left(\mathrm{CH}_{2} \mathrm{P},{ }^{1} J_{\mathrm{PC}}=\right.$ 
$143.3 \mathrm{~Hz}), 30.18\left(\mathrm{CH}_{3}\right.$-acetyl $), 40.15\left(\underline{\mathrm{CH}}_{2} \mathrm{CO}\right), 61.79$ $\left(\mathrm{CH}_{2} \mathrm{O}\right.$-ester $), 106.54 \mathrm{~d}\left(\mathrm{C}^{4}\right.$-furan, $\left.{ }^{3} J_{\mathrm{PC}}=7.2 \mathrm{~Hz}\right), 168.70$ (C=O-ester), 186.32 ( $\mathrm{C}=\mathrm{O}$-furan), $202.17(\mathrm{C}=\mathrm{O}$-acetyl).

${ }^{31} \mathrm{P}$ NMR spectrum $\left(\mathrm{CDCl}_{3}\right), \delta_{\mathrm{P}}, \mathrm{ppm}: 25.65$.

2-\{2-[5-(Diethoxyphosphorylmethyl)fur-2-yl]-2oxoethyl\}-3-hydroxycyclohex-2-en-1-one (1c). Yield $46 \%$, light brown syrup. ${ }^{1} \mathrm{H}$ NMR spectrum $\left(\mathrm{CDCl}_{3}\right), \delta$, ppm: $1.24-1.31 \mathrm{~m}\left(6 \mathrm{H}, \mathrm{CH}_{3}\right.$-phosphonate), 2.15 quintet $\left(2 \mathrm{H}, \mathrm{C}^{5} \mathrm{H}_{2}\right.$-cycloxehyl, $\left.J_{\mathrm{HH}}=6.4 \mathrm{~Hz}\right), 2.52 \mathrm{t}\left(2 \mathrm{H}, \mathrm{C}^{4} \mathrm{H}_{2^{-}}\right.$ cyclohexyl, $\left.J_{\mathrm{HH}}=6.4 \mathrm{~Hz}\right), 2.87 \mathrm{t}\left(2 \mathrm{H}, \mathrm{C}^{6} \mathrm{H}_{2}\right.$-cyclohexyl, $\left.J_{\mathrm{HH}}=6.4 \mathrm{~Hz}\right), 3.29 \mathrm{~d}\left(2 \mathrm{H}, \mathrm{CH}_{2} \mathrm{P}, J_{\mathrm{PH}}=21.2 \mathrm{~Hz}\right), 3.39 \mathrm{~d}$ $\left(1 \mathrm{H}, \mathrm{CH}_{2}, \mathrm{H}_{\mathrm{A}}, J_{\mathrm{AB}}=12.4 \mathrm{~Hz}\right), 3.33 \mathrm{~d}\left(1 \mathrm{H}, \mathrm{CH}_{2}, \mathrm{H}_{\mathrm{B}}\right.$, $\left.J_{\mathrm{AB}}=12.4 \mathrm{~Hz}\right), 4.02-4.14 \mathrm{~m}\left(4 \mathrm{H}, \mathrm{CH}_{2} \mathrm{O}-\right.$ phosphonate), 6.26 d.d $\left(1 \mathrm{H}, \mathrm{H}^{4}\right.$-furan, $\left.J_{\mathrm{HH}}=3.2 \mathrm{~Hz}, J_{\mathrm{PH}}=3.2 \mathrm{~Hz}\right)$, $7.32 \mathrm{~d}\left(1 \mathrm{H}, \mathrm{H}^{3}\right.$-furan, $\left.J_{\mathrm{HH}}=3.2 \mathrm{~Hz}\right), 7.64 \mathrm{~s}(1 \mathrm{H}, \mathrm{OH})$. ${ }^{13} \mathrm{C}$ NMR spectrum $\left(\mathrm{CDCl}_{3}\right), \delta_{\mathrm{C}}, \mathrm{ppm}: 16.36 \mathrm{~d}\left(\mathrm{CH}_{3^{-}}\right.$ phosphonate, $\left.{ }^{3} J_{\mathrm{PC}}=6.0 \mathrm{~Hz}\right), 22.26\left(\mathrm{C}^{5}\right.$-cyclohexyl $)$, $26.80 \mathrm{~d}\left(\mathrm{CH}_{2} \mathrm{P},{ }^{1} J_{\mathrm{PC}}=142.5 \mathrm{~Hz}\right), 29.78\left(\mathrm{C}^{6}\right.$-cyclohexyl), 32.28 ( $\mathrm{C}^{4}$-cyclohexyl), $38.61\left(\underline{\mathrm{CH}}_{2} \mathrm{CO}\right), 62.37 \mathrm{~d}\left(\mathrm{CH}_{2} \mathrm{O}-\right.$ phosphonate, $\left.{ }^{2} J_{\mathrm{PC}}=6.6 \mathrm{~Hz}\right), 110.21 \mathrm{~d}\left(\mathrm{C}^{4}\right.$-furan, ${ }^{3} J_{\mathrm{PC}}=$ 7.6 Hz), 112.02 ( $\mathrm{C}^{2}$-cyclohexyl), 112.05 ( $\mathrm{C}^{2}$-cyclohexyl), $120.81 \mathrm{~d}\left(\mathrm{C}^{3}\right.$-furan, $\left.{ }^{4} J_{\mathrm{PC}}=3.2 \mathrm{~Hz}\right), 149.60 \mathrm{~d}\left(\mathrm{C}^{2}\right.$-furan, $\left.{ }^{4} J_{\mathrm{PC}}=2.9 \mathrm{~Hz}\right), 152.39 \mathrm{~d}\left(\mathrm{C}^{5}\right.$-furan, $\left.{ }^{2} J_{\mathrm{PC}}=8.7 \mathrm{~Hz}\right), 179.65$ ( $\mathrm{C}=\mathrm{O}$-furan), $190.99\left(\mathrm{C}^{3}\right.$-cyclohexyl), $193.80(\mathrm{C}=\mathrm{O}-$ cyclohexyl). ${ }^{31} \mathrm{P}$ NMR spextrum $\left(\mathrm{CDCl}_{3}\right), \delta_{\mathrm{P}}, \mathrm{ppm}: 22.74$.

2-\{2-[5-Methyl-4-(diethoxyphosphorylmethyl)fur-2-yl]-2-oxoethyl\}-3-hydroxycyclohex-2-en-1-one (2c). Yield 39\%, light brown syrup. ${ }^{1} \mathrm{H}$ NMR spectrum $\left(\mathrm{CDCl}_{3}\right), \delta$, ppm: common signals: $1.23-1.33 \mathrm{~m}(6 \mathrm{H}$, $\mathrm{CH}_{3}$-phosphonate), $1.85-1.93 \mathrm{~m}$ and $1.97-2.04 \mathrm{~m}(2 \mathrm{H}$, $\mathrm{C}^{5} \mathrm{H}_{2}$-cyclohexyl), 2.24-2.34 $\mathrm{m}$ and $2.37-2.46 \mathrm{~m}(3 \mathrm{H}$, $\mathrm{CH}_{2}$-cyclohexyl), 2.48-2.55 m (1H, $\mathrm{CH}_{2}$-cyclohexyl), $2.87 \mathrm{~d}\left(2 \mathrm{H}, \mathrm{CH}_{2} \mathrm{P}, J_{\mathrm{PH}}=20.8 \mathrm{~Hz}\right), 4.02-4.11 \mathrm{~m}(4 \mathrm{H}$, $\mathrm{CH}_{2} \mathrm{O}$-phosphonate); main conformer: $2.35 \mathrm{~d}(3 \mathrm{H}$, $\mathrm{CH}_{3}$-furan, $\left.J_{\mathrm{PH}}=2.4 \mathrm{~Hz}\right), 3.37 \mathrm{~d}\left(1 \mathrm{H}, \mathrm{CH}_{2}, \mathrm{H}_{\mathrm{A}}, J_{\mathrm{AB}}=\right.$ $9.2 \mathrm{~Hz}), 3.47 \mathrm{~d}\left(1 \mathrm{H}, \mathrm{CH}_{2}, \mathrm{H}_{\mathrm{B}}, J_{\mathrm{AB}}=9.2 \mathrm{~Hz}\right), 7.22 \mathrm{~s}(1 \mathrm{H}$, $\mathrm{H}^{4}$-furan), $8.19 \mathrm{~s}(1 \mathrm{H}, \mathrm{OH})$; minor conformer: $2.39 \mathrm{~d}(3 \mathrm{H}$, $\mathrm{CH}_{3}$-furan, $\left.J_{\mathrm{PH}}=2.4 \mathrm{~Hz}\right), 3.41 \mathrm{~d}\left(1 \mathrm{H}, \mathrm{CH}_{2}, \mathrm{H}_{\mathrm{A}}, J_{\mathrm{AB}}=\right.$ $3.6 \mathrm{~Hz}), 3.48 \mathrm{~d}\left(1 \mathrm{H}, \mathrm{CH}_{2}, \mathrm{H}_{\mathrm{B}}, J_{\mathrm{AB}}=3.6 \mathrm{~Hz}\right), 7.21 \mathrm{~s}(1 \mathrm{H}$, $\mathrm{H}^{4}$-furan), $8.06 \mathrm{~s}(1 \mathrm{H}, \mathrm{OH})$; conformer ratio $1: 0.8 .{ }^{13} \mathrm{C}$ NMR signals $\left(\mathrm{CDCl}_{3}\right), \delta_{\mathrm{C}}$, ppm: common signals: $16.43 \mathrm{~d}$ $\left(\mathrm{CH}_{3}\right.$-phosphonate, $\left.{ }^{3} J_{\mathrm{PC}}=5.8 \mathrm{~Hz}\right), 23.15 \mathrm{~d}\left(\mathrm{CH}_{2} \mathrm{P}\right.$, $\left.{ }^{1} J_{\mathrm{PC}}=143.6 \mathrm{~Hz}\right), 62.30 \mathrm{~d}\left(\mathrm{CH}_{2} \mathrm{O}-\right.$ phosphonate, ${ }^{2} J_{\mathrm{PC}}=$ $6.7 \mathrm{~Hz}), 113.52 \mathrm{~d}\left(\mathrm{C}^{4}\right.$-furan, $\left.{ }^{2} J_{\mathrm{PC}}=9.3 \mathrm{~Hz}\right), 155.70 \mathrm{~d}\left(\mathrm{C}^{5}-\right.$ furan, $\left.{ }^{3} J_{\mathrm{PC}}=10.0 \mathrm{~Hz}\right), 179.82(\mathrm{C}=\mathrm{O}$-furan $), 186.70\left(\mathrm{C}^{3}-\right.$ cyclohexyl), 191.13 (C=O-cyclohexyl); main conformer: 12.23 br.s $\left(\mathrm{CH}_{3}\right.$-furan), 19.84 ( $\mathrm{C}^{5}$-cyclohexyl), 30.90 ( $\mathrm{C}^{6}$-cyclohexyl), 32.28 ( $\mathrm{C}^{4}$-cyclohexyl), $38.07\left(\underline{\mathrm{CH}}_{2} \mathrm{CO}\right)$, $115.63\left(\mathrm{C}^{2}\right.$-cyclohexyl), $120.92 \mathrm{~d}\left(\mathrm{C}^{3}\right.$-furan, ${ }^{3} J_{\mathrm{PC}}=$
$2.7 \mathrm{~Hz}), 148.18$ ( $\mathrm{C}^{2}$-furan); minor conformer: $12.43 \mathrm{~d}$ $\left(\mathrm{CH}_{3}\right.$-furan, $\left.{ }^{4} J_{\mathrm{PC}}=1.1 \mathrm{~Hz}\right), 20.22\left(\mathrm{C}^{5}\right.$-cyclohexyl $), 30.96$ ( $\mathrm{C}^{6}$-cyclohexyl), 32.97 ( $\mathrm{C}^{4}$-cyclohexyl), $36.95\left(\underline{\mathrm{CH}}_{2} \mathrm{CO}\right)$, $114.666\left(\mathrm{C}^{2}\right.$-cyclohexyl), $121.06 \mathrm{~d}\left(\mathrm{C}^{3}\right.$-furan, ${ }^{3} J_{\mathrm{PC}}=$ $3.0 \mathrm{~Hz}), 148.00\left(\mathrm{C}^{2}\right.$-furan $) .{ }^{31} \mathrm{P} \mathrm{NMR}$ spectrum $\left(\mathrm{CDCl}_{3}\right)$, $\delta_{\mathrm{P}}, \mathrm{ppm}: 25.32(1), 25.39(0.8)$.

2-\{2-[3-(Diethoxyphosphorylmethyl)fur-2-yl]-2oxoethyl\}-3-hydroxycyclohex-2-en-1-one (3c). Yield $81 \%$, light red syrup. ${ }^{1} \mathrm{H}$ NMR spectrum $\left(\mathrm{CDCl}_{3}\right), \delta$, ppm: $1.26 \mathrm{t}\left(6 \mathrm{H}, \mathrm{CH}_{3}\right.$-phosphonate, $\left.J_{\mathrm{PH}}=7.2 \mathrm{~Hz}\right), 1.93$ br.q $(2 \mathrm{H}$, $\mathrm{C}^{5} \mathrm{H}_{2}$-cyclohexyl, $\left.J_{\mathrm{HH}}=6.4 \mathrm{~Hz}\right), 2.33-2.41 \mathrm{~m}\left(2 \mathrm{H}, \mathrm{CH}_{2^{-}}\right.$ cyclohexyl), 2.43-2.58 m (2H, $\mathrm{CH}_{2}$-cyclohexyl), $3.53 \mathrm{~d}$ $\left(2 \mathrm{H}, \mathrm{CH}_{2} \mathrm{P}, J_{\mathrm{PH}}=22.4 \mathrm{~Hz}\right), 3.51 \mathrm{~d}\left(1 \mathrm{H}, \mathrm{CH}_{2}, \mathrm{H}_{\mathrm{A}}, J_{\mathrm{AB}}=\right.$ $14.4 \mathrm{~Hz}), 3.57 \mathrm{~d}\left(1 \mathrm{H}, \mathrm{CH}_{2}, \mathrm{H}_{\mathrm{B}}, J_{\mathrm{AB}}=14.4 \mathrm{~Hz}\right), 4.01-$ $4.16 \mathrm{~m}\left(4 \mathrm{H}, \mathrm{CH}_{2} \mathrm{O}\right.$-hosphonate), 6.72 br.s $\left(1 \mathrm{H}, \mathrm{H}^{4}\right.$-furan $)$, 7.49 br.s (1H, $\mathrm{H}^{5}$-furan), $8.22 \mathrm{~s}(1 \mathrm{H}, \mathrm{OH}) .{ }^{13} \mathrm{C} \mathrm{NMR}$ spectrum $\left(\mathrm{CDCl}_{3}\right), \delta_{\mathrm{C}}$, ppm: $16.30 \mathrm{~d}\left(\mathrm{CH}_{3}\right.$-phosphonate, $\left.{ }^{3} J_{\mathrm{PC}}=5.9 \mathrm{~Hz}\right), 16.33 \mathrm{~d}\left(\mathrm{CH}_{3}-\right.$ phosphonate, $\left.{ }^{3} J_{\mathrm{PC}}=6.2 \mathrm{~Hz}\right)$, 19.75 (C $\mathrm{C}^{5}$-cyclohexyl), $23.41 \mathrm{~d}\left(\mathrm{CH}_{2} \mathrm{P},{ }^{1} J_{\mathrm{PC}}=139.0 \mathrm{~Hz}\right)$, 31.03 br.s ( $\mathrm{C}^{6}$-cyclohexyl), 32.79 br.s ( $\mathrm{C}^{4}$-cyclohexyl), $38.75\left(\mathrm{CH}_{2} \mathrm{CO}\right), 62.34 \mathrm{~d}\left(\mathrm{CH}_{2} \mathrm{O}\right.$-phosphonate, ${ }^{2} J_{\mathrm{PC}}=$ $6.6 \mathrm{~Hz}), 112.96$ ( $\mathrm{C}^{2}$-cyclohexyl), $115.67 \mathrm{~d}\left(\mathrm{C}^{4}\right.$-furan, $\left.{ }^{3} J_{\mathrm{PC}}=3.1 \mathrm{~Hz}\right), 126.65 \mathrm{~d}\left(\mathrm{C}^{3}\right.$-furan, $\left.{ }^{2} J_{\mathrm{PC}}=9.8 \mathrm{~Hz}\right), 145.53 \mathrm{~d}$ $\left(\mathrm{C}^{5}\right.$-furan, $\left.{ }^{4} J_{\mathrm{PC}}=2.2 \mathrm{~Hz}\right), 146.36 \mathrm{~d}\left(\mathrm{C}^{2}\right.$-furan, ${ }^{3} J_{\mathrm{PC}}=$ $10.1 \mathrm{~Hz}), 182.07 \mathrm{~d}\left(\mathrm{C}=\mathrm{O}\right.$-furan, $\left.{ }^{4} J_{\mathrm{PC}}=2.4 \mathrm{~Hz}\right), 191.04$ (C $\mathrm{C}^{3}$-cyclohexyl), 191.32 (C=O-cyclohexyl). ${ }^{31} \mathrm{P}$ NMR spectrum $\left(\mathrm{CDCl}_{3}\right), \delta_{\mathrm{P}}$, ppm: 24.31 .

2-\{2-[2-(Diethoxyphosphorylmethyl)fur-3-yl]-2oxoethyl\}-3-hydroxycyclohex-2-en-1-one (4c). Yield $29 \%$, light brown syrup. ${ }^{1} \mathrm{H}$ NMR spectrum $\left(\mathrm{CDCl}_{3}\right)$, $\delta$, ppm: $1.23-1.34 \mathrm{~m}\left(6 \mathrm{H}, \mathrm{CH}_{3}\right.$-phosphonate), 1.90 br.q $\left(2 \mathrm{H}, \mathrm{C}^{5} \mathrm{H}_{2}\right.$-cyclohexyl, $\left.J_{\mathrm{HH}}=6.0 \mathrm{~Hz}\right), 2.30-2.35 \mathrm{~m}(3 \mathrm{H}$, $\mathrm{CH}_{2}$-cyclohexyl), 2.41-2.50 m (1H, $\mathrm{CH}_{2}$-cyclohexyl), $3.37 \mathrm{~d}\left(2 \mathrm{H}, \mathrm{CH}_{2} \mathrm{P}, J_{\mathrm{PH}}=22.8 \mathrm{~Hz}\right), 3.73 \mathrm{~d}\left(1 \mathrm{H}, \mathrm{CH}_{2}, \mathrm{H}_{\mathrm{A}}\right.$, $\left.J_{\mathrm{AB}}=14.2 \mathrm{~Hz}\right), 3.77 \mathrm{~d}\left(1 \mathrm{H}, \mathrm{CH}_{2}, \mathrm{H}_{\mathrm{B}}, J_{\mathrm{AB}}=14.2 \mathrm{~Hz}\right)$, 4.05-4.14 m (4H, $\mathrm{CH}_{2} \mathrm{O}$-phosphonate), $6.70 \mathrm{~d}(1 \mathrm{H}$, $\mathrm{H}^{4}$-furan, $\left.J_{\mathrm{HH}}=2.0 \mathrm{~Hz}\right), 7.39 \mathrm{~d}\left(1 \mathrm{H}, \mathrm{H}^{5}\right.$-furan, $J_{\mathrm{HH}}=$ $2.0 \mathrm{~Hz}), 8.19 \mathrm{~s}(1 \mathrm{H}, \mathrm{OH}) .{ }^{13} \mathrm{C} \mathrm{NMR}$ spectrum $\left(\mathrm{CDCl}_{3}\right)$, $\delta_{\mathrm{C}}$, ppm: $16.27 \mathrm{~d}\left(\mathrm{CH}_{3}\right.$-phosphonate, $\left.{ }^{3} J_{\mathrm{PC}}=6.0 \mathrm{~Hz}\right)$, 20.29 ( $\mathrm{C}^{5}$-cyclohexyl), $27.07 \mathrm{~d}\left(\mathrm{CH}_{2} \mathrm{P},{ }^{1} J_{\mathrm{PC}}=137.7 \mathrm{~Hz}\right)$, 30.90 ( $\mathrm{C}^{6}$-cyclohexyl), 32.37 ( $\mathrm{C}^{4}$-cyclohexyl), 40.30 $\left(\mathrm{CH}_{2} \mathrm{CO}\right), 41.43\left(\underline{\mathrm{CH}}_{2} \mathrm{CO}\right), 62.56 \mathrm{~d}\left(\mathrm{CH}_{2} \mathrm{O}\right.$-phosphonate, $\left.{ }^{2} J_{\mathrm{PC}}=6.2 \mathrm{~Hz}\right), 62.62 \mathrm{~d}\left(\mathrm{CH}_{2} \mathrm{O}\right.$-phosphonate, ${ }^{2} J_{\mathrm{PC}}=$ $5.7 \mathrm{~Hz}), 110.48 \mathrm{~d}\left(\mathrm{C}^{4}\right.$-furan, $\left.{ }^{4} J_{\mathrm{PC}}=2.4 \mathrm{~Hz}\right), 110.81\left(\mathrm{C}^{2}-\right.$ cyclohexyl), $115.99 \mathrm{~d}\left(\mathrm{C}^{3}\right.$-furan, $\left.{ }^{3} J_{\mathrm{PC}}=7.7 \mathrm{~Hz}\right), 141.95 \mathrm{~d}$ $\left(\mathrm{C}^{5}\right.$-furan, $\left.{ }^{4} J_{\mathrm{PC}}=2.1 \mathrm{~Hz}\right), 156.49 \mathrm{~d}\left(\mathrm{C}^{2}\right.$-furan, ${ }^{2} J_{\mathrm{PC}}=$ $13.6 \mathrm{~Hz}), 187.06 \mathrm{~d}\left(\mathrm{C}=\mathrm{O}\right.$-furan, $\left.{ }^{4} J_{\mathrm{PC}}=2.0 \mathrm{~Hz}\right), 187.39$ (C $\mathrm{C}^{3}$-cyclohexyl), 191.02 (C=O-cyclohexyl). ${ }^{31} \mathrm{P} \mathrm{NMR}$ spectrum $\left(\mathrm{CDCl}_{3}\right), \delta_{\mathrm{P}}$, M.d.: 20.66 . 
2-\{2-[5-(Diethoxyphosphorylmethyl)fur-3-yl]-2oxoethyl\}-3-hydroxycyclohex-2-en-1-one (6c). Yield $63 \%$, light yellow syrup. ${ }^{1} \mathrm{H}$ NMR spectrum $\left(\mathrm{CDCl}_{3}\right)$, $\delta$, ppm: $1.23 \mathrm{t}\left(6 \mathrm{H}, \mathrm{CH}_{3}\right.$-phosphonate, $\left.J_{\mathrm{HH}}=7.0 \mathrm{~Hz}\right)$, 1.80-2.02 m (2H, $\mathrm{C}^{5} \mathrm{H}_{2}$-cyclohexyl), 2.21-2.36 m (3H, $\mathrm{CH}_{2}$-cyclohexyl), 2.42-2.50 m (1H, $\mathrm{CH}_{2}$-cyclohexyl), $3.13 \mathrm{~d}\left(1 \mathrm{H}, \mathrm{CH}_{2}, \mathrm{H}_{\mathrm{A}}, J_{\mathrm{AB}}=4.0 \mathrm{~Hz}\right), 3.18\left(2 \mathrm{H}, \mathrm{CH}_{2} \mathrm{P}\right.$, $\left.J_{\mathrm{PH}}=20.8 \mathrm{~Hz}\right), 3.18 \mathrm{~d}\left(1 \mathrm{H}, \mathrm{CH}_{2}, \mathrm{H}_{\mathrm{B}}, J_{\mathrm{AB}}=4.0 \mathrm{~Hz}\right), 6.55 \mathrm{~d}$ $\left(1 \mathrm{H}, \mathrm{H}^{4}\right.$-furan, $\left.J_{\mathrm{PH}}=3.2 \mathrm{~Hz}\right), 8.03 \mathrm{~s}\left(1 \mathrm{H}, \mathrm{H}^{2}\right.$-furan $), 8.13 \mathrm{~s}$ $(1 \mathrm{H}, \mathrm{OH}) .{ }^{13} \mathrm{C}$ NMR spectrum $\left(\mathrm{CDCl}_{3}\right), \delta_{\mathrm{C}}, \mathrm{ppm}: 16.29 \mathrm{~d}$ $\left(\mathrm{CH}_{3}\right.$-phosphonate, $\left.{ }^{3} \mathrm{JC}_{\mathrm{PC}}=5.9 \mathrm{~Hz}\right), 20.46\left(\mathrm{C}^{5}\right.$-cyclohexyl), 20.99 (C $\mathrm{C}^{5}$-cyclohexyl), 25.69 ( $\mathrm{C}^{6}$-cyclohexyl), $26.41 \mathrm{~d}$ $\left(\mathrm{CH}_{2} \mathrm{P},{ }^{1} J_{\mathrm{PC}}=142.9 \mathrm{~Hz}\right), 27.12\left(\mathrm{C}^{6}\right.$-cyclohexyl), 32.91 (C4-cyclohexyl), 33.59 ( $\mathrm{C}^{4}$ - cyclohexyl), $36.54\left(\underline{\mathrm{CH}}_{2} \mathrm{CO}\right)$, $62.57 \mathrm{~d}\left(\mathrm{CH}_{2} \mathrm{O}-\right.$ phosphonate, $\left.{ }^{2} J_{\mathrm{PC}}=6.6 \mathrm{~Hz}\right), 106.49 \mathrm{~d}$ $\left(\mathrm{C}^{4}\right.$-furan, $\left.{ }^{3} J_{\mathrm{PC}}=7.2 \mathrm{~Hz}\right), 115.60\left(\mathrm{C}^{2}\right.$-cyclohexyl $), 125.14 \mathrm{~d}$ $\left(\mathrm{C}^{3}\right.$-furan, $\left.{ }^{4} J_{\mathrm{PC}}=2.7 \mathrm{~Hz}\right), 146.80 \mathrm{~d}\left(\mathrm{C}^{2}\right.$-furan, ${ }^{4} J_{\mathrm{PC}}=$ $1.9 \mathrm{~Hz}), 148.49 \mathrm{~d}\left(\mathrm{C}^{5}\right.$-furan, $\left.{ }^{2} J_{\mathrm{PC}}=8.3 \mathrm{~Hz}\right), 185.35$ (C=O-furan), $191.44\left(\mathrm{C}^{3}\right.$-cyclohexyl), $191.62(\mathrm{C}=\mathrm{O}-$ cyclohexyl). ${ }^{31} \mathrm{P}$ NMR spectrum $\left(\mathrm{CDCl}_{3}\right), \delta_{\mathrm{p}}, \mathrm{ppm}: 21.79$.

Reaction of 2-acetyl-4-[(diethoxyphosphorylmethyl)furyl]-4-oxobutanoates with hydrazine hydrate. To a solution of $5 \mathrm{mmol}$ of 1,4-diketone in $15 \mathrm{~mL}$ of ethanol, $5.2 \mathrm{mmol}$ of hydrazine hydrate was added in one portion. The resulting mixture was stirred for $15 \mathrm{~min}$ until homogenization and left for $12 \mathrm{~h}$ at room temperature. After that, ethanol was distilled off, the residue was dissolved in $25 \mathrm{~mL}$ of methylene chloride, washed with water $(2 \times 10 \mathrm{~mL})$, with $10 \mathrm{~mL}$ of brine, and dried over sodium sulfate. Methylene chloride was distilled off, the residue was kept in a vacuum $(1 \mathrm{mmHg})$ for $1 \mathrm{~h}$ at room temperature.

Ethyl 3-methyl-6-[5-(diethoxyphosphrylmethyl)fur-2-yl]pyridazin-4-carboxylate 1d. Yield 53\%, light yellow glass. ${ }^{1} \mathrm{H} \mathrm{NMR}$ spectrum $\left(\mathrm{CDCl}_{3}\right), \delta$, ppm: 1.24 $1.32 \mathrm{~m}\left(9 \mathrm{H}, \mathrm{CH}_{3}\right.$-ester, $\mathrm{CH}_{3}$-phosphonate), $2.25 \mathrm{~s}(3 \mathrm{H}$, $\left.\mathrm{CH}_{3}\right), 3.28 \mathrm{~d}\left(2 \mathrm{H}, \mathrm{CH}_{2} \mathrm{P}, J_{\mathrm{PH}}=20.8 \mathrm{~Hz}\right), 4.04 \mathrm{~d} . \mathrm{q}(4 \mathrm{H}$, $\mathrm{CH}_{2} \mathrm{O}$-phosphonate, $\left.J_{\mathrm{HH}}=7.2 \mathrm{~Hz}, J_{\mathrm{PH}}=14.4 \mathrm{~Hz}\right), 4.18 \mathrm{q}$ $\left(2 \mathrm{H}, \mathrm{CH}_{2} \mathrm{O}\right.$-ester, $\left.J_{\mathrm{HH}}=7.2 \mathrm{~Hz}\right), 6.36$ d.d $\left(1 \mathrm{H}, \mathrm{H}^{4}\right.$-furan, $\left.J_{\mathrm{HH}}=3.2 \mathrm{~Hz}, J_{\mathrm{PH}}=3.2 \mathrm{~Hz}\right), 7.29 \mathrm{~d}\left(1 \mathrm{H}, \mathrm{H}^{3}\right.$-furan, $J_{\mathrm{HH}}=$ $3.2 \mathrm{~Hz}), 8.09 \mathrm{~s}\left(1 \mathrm{H}, \mathrm{H}^{5}\right.$-pyridazine). ${ }^{13} \mathrm{C} \mathrm{NMR}$ spectrum $\left(\mathrm{CDCl}_{3}\right), \delta_{\mathrm{C}}, \mathrm{ppm}: 14.53\left(\mathrm{CH}_{3}\right.$-ester $), 16.35 \mathrm{~d}\left(\mathrm{CH}_{3}\right.$ phosphonate, $\left.{ }^{3} J_{\mathrm{PC}}=5.8 \mathrm{~Hz}\right), 16.38 \mathrm{~d}\left(\mathrm{CH}_{3}\right.$-phosphonate, $\left.{ }^{3} J_{\mathrm{PC}}=5.7 \mathrm{~Hz}\right), 17.61\left(\mathrm{CH}_{3}\right), 27.07 \mathrm{~d}\left(\mathrm{CH}_{2} \mathrm{P},{ }^{1} J_{\mathrm{PC}}=\right.$ $142.8 \mathrm{~Hz}), 59.69\left(\mathrm{CH}_{2} \mathrm{O}\right.$-ester $), 62.52 \mathrm{~d}\left(\mathrm{CH}_{2} \mathrm{O}-\right.$ phosphonate, $\left.{ }^{3} J_{\mathrm{PC}}=6.5 \mathrm{~Hz}\right), 62.54 \mathrm{~d}\left(\mathrm{CH}_{2} \mathrm{O}\right.$-phosphonate, $\left.{ }^{3} J_{\mathrm{PC}}=6.8 \mathrm{~Hz}\right), 110.28 \mathrm{~d}\left(\mathrm{C}^{4}\right.$-furan, $\left.{ }^{3} J_{\mathrm{PC}}=6.3 \mathrm{~Hz}\right), 111.85 \mathrm{~d}$ (C $\mathrm{C}^{3}$-furan, $\left.{ }^{4} J_{\mathrm{PC}}=3.3 \mathrm{~Hz}\right), 121.41\left(\mathrm{C}^{5}\right.$-pyridazine $), 128.75$ (C $\mathrm{C}^{4}$-pyridazine), 137.21 ( $\mathrm{C}^{6}$-pyridazine $), 146.51\left(\mathrm{C}^{3}\right.$ - pyridazine $), 148.48 \mathrm{~d}\left(\mathrm{C}^{5}\right.$-furan, $\left.{ }^{2} J_{\mathrm{PC}}=9.4 \mathrm{~Hz}\right), 150.06 \mathrm{~d}$ ( $\mathrm{C}^{2}$-furan, $\left.{ }^{4} J_{\mathrm{PC}}=3.5 \mathrm{~Hz}\right), 165.02(\mathrm{C}=\mathrm{O}) .{ }^{31} \mathrm{P} \mathrm{NMR}$ spectrum $\left(\mathrm{CDCl}_{3}\right), \delta_{\mathrm{P}}$, ppm: 22.41 .

Ethyl 3-methyl-6-[4-(diethoxyphosphorylmethyl)5-methylfur-2-yl]pyridazin-4-carboxylate (2d). Yield $44 \%$, light brown glass. ${ }^{1} \mathrm{H}$ NMR spectrum $\left(\mathrm{CDCl}_{3}\right), \delta$, ppm: 1.23-1.33 m (9H, $\mathrm{CH}_{3}$-ester, $\mathrm{CH}_{3}$-phosphonate), $2.24 \mathrm{~s}\left(3 \mathrm{H}, \mathrm{CH}_{3}\right), 2.29 \mathrm{~d}\left(3 \mathrm{H}, \mathrm{CH}_{3}\right.$-furan, $\left.J_{\mathrm{PH}}=3.3 \mathrm{~Hz}\right)$, 2.90 d $\left(2 \mathrm{H}, \mathrm{CH}_{2} \mathrm{P}, J_{\mathrm{PH}}=20.4 \mathrm{~Hz}\right), 4.06$ d.q $\left(4 \mathrm{H}, \mathrm{CH}_{2} \mathrm{O}-\right.$ phosphonate, $\left.J_{\mathrm{HH}}=7.2 \mathrm{~Hz}, J_{\mathrm{PH}}=15.2 \mathrm{~Hz}\right), 4.16 \mathrm{q}(2 \mathrm{H}$, $\mathrm{CH}_{2} \mathrm{O}$-ester, $\left.J_{\mathrm{HH}}=7.0 \mathrm{~Hz}\right), 7.23 \mathrm{~s}\left(1 \mathrm{H}, \mathrm{H}^{3}\right.$-furan $), 8.05 \mathrm{~s}$ $\left(1 \mathrm{H}, \mathrm{H}^{5}\right.$-pyridazine). ${ }^{13} \mathrm{C}$ NMR spectrum $\left(\mathrm{CDCl}_{3}\right), \delta_{\mathrm{C}}$, ppm: $11.84 \mathrm{~d}\left(\mathrm{CH}_{3}\right.$-furan, $\left.{ }^{4} \mathrm{~J}_{\mathrm{PC}}=2.0 \mathrm{~Hz}\right), 14.55\left(\mathrm{CH}_{3}-\right.$ ester), $16.43 \mathrm{~d}\left(\mathrm{CH}_{3}\right.$-phosphonate, $\left.{ }^{3} J_{\mathrm{PC}}=5.9 \mathrm{~Hz}\right), 17.60$ $\left(\mathrm{CH}_{3}\right), 23.30 \mathrm{~d}\left(\mathrm{CH}_{2} \mathrm{P},{ }^{1} J_{\mathrm{PC}}=143.1 \mathrm{~Hz}\right), 59.64\left(\mathrm{CH}_{2} \mathrm{O}-\right.$ ester $), 62.11 \mathrm{~d}\left(\mathrm{CH}_{2} \mathrm{O}\right.$-phosphonate, $\left.{ }^{3} J_{\mathrm{PC}}=6.7 \mathrm{~Hz}\right)$, $111.42 \mathrm{~d}\left(\mathrm{C}^{4}\right.$-furan, $\left.{ }^{2} J_{\mathrm{PC}}=9.6 \mathrm{~Hz}\right), 113.96 \mathrm{~s}\left(\mathrm{C}^{3}\right.$-furan $)$, 124.17 ( $\mathrm{C}^{5}$-pyridazine), 124.20 ( $\mathrm{C}^{5}$-pyridazine), 128.29 (C $\mathrm{C}^{4}$-pyridazine), $128.49\left(\mathrm{C}^{4}\right.$-pyridazine $), 137.36\left(\mathrm{C}^{6}\right.$ pyridazine), 146.49 ( $\mathrm{C}^{3}$-pyridazine), $148.34\left(\mathrm{C}^{2}\right.$-furan), $151.49 \mathrm{~d}\left(\mathrm{C}^{5}\right.$-furan, $\left.{ }^{3} J_{\mathrm{PC}}=11.2 \mathrm{~Hz}\right), 165.14(\mathrm{C}=\mathrm{O})$, $165.20(\mathrm{C}=\mathrm{O}) .{ }^{31} \mathrm{P}$ NMR spectrum $\left(\mathrm{CDCl}_{3}\right), \delta_{\mathrm{P}}, \mathrm{ppm}$ : 26.34 .

Ethyl 3-methyl-6-[2-(diethoxyphosphorylmethyl)fur-3-yl]pyridazin-4-carboxylate (4d). Yield 33\%, light brown glass. ${ }^{1} \mathrm{H}$ NMR spectrum $\left(\mathrm{CDCl}_{3}\right), \delta$, ppm: 1.18-1.32 m (9H, $\mathrm{CH}_{3}$-ester, $\mathrm{CH}_{3}$-phosphonate), $2.24 \mathrm{~s}$ $\left(3 \mathrm{H}, \mathrm{CH}_{3}\right), 3.96 \mathrm{~d}\left(2 \mathrm{H}, \mathrm{CH}_{2} \mathrm{P}, J_{\mathrm{PH}}=21.2 \mathrm{~Hz}\right), 4.02-4.12 \mathrm{~m}$ (4H, $\mathrm{CH}_{2} \mathrm{O}$-phosphonate), 4.15 q $\left(\mathrm{CH}_{2} \mathrm{O}\right.$-ester, $J_{\mathrm{HH}}=$ $7.2 \mathrm{~Hz}$ ), 6.80 br.s (1 $\mathrm{H}, \mathrm{H}^{4}$-furan), 7.49 br.s $\left(1 \mathrm{H}, \mathrm{H}^{5}\right.$-furan), $7.97 \mathrm{~s}\left(1 \mathrm{H}, \mathrm{H}^{5}\right.$-pyridazine $) .{ }^{13} \mathrm{C}$ NMR spectrum $\left(\mathrm{CDCl}_{3}\right)$, $\delta_{\mathrm{C}}$, ppm: $14.50\left(\mathrm{CH}_{3}\right.$-ester $), 16.27 \mathrm{~d}\left(\mathrm{CH}_{3}\right.$-phosphonate, $\left.{ }^{3} J_{\mathrm{PC}}=6.1 \mathrm{~Hz}\right), 16.31 \mathrm{~d}\left(\mathrm{CH}_{3}\right.$-phosphonate, ${ }^{3} J_{\mathrm{PC}}=$ $5.9 \mathrm{~Hz}), 17.54\left(\mathrm{CH}_{3}\right), 26.62 \mathrm{~d}\left(\mathrm{CH}_{2} \mathrm{P},{ }^{1} J_{\mathrm{PC}}=139.8 \mathrm{~Hz}\right)$, $59.59\left(\mathrm{CH}_{2} \mathrm{O}\right.$-ester $), 62.28$ d $\left(\mathrm{CH}_{2} \mathrm{O}\right.$-phosphonate, $\left.{ }^{3} J_{\mathrm{PC}}=6.4 \mathrm{~Hz}\right), 109.83 \mathrm{~d}\left(\mathrm{C}^{4}-\right.$ furan, $\left.{ }^{4} J_{\mathrm{PC}}=2.9 \mathrm{~Hz}\right), 119.67 \mathrm{~d}$ $\left(\mathrm{C}^{3}\right.$-furan, $\left.{ }^{3} J_{\mathrm{PC}}=9.5 \mathrm{~Hz}\right), 124.06\left(\mathrm{C}^{5}\right.$-pyridazine $), 128.51$ (C $\mathrm{C}^{4}$-pyridazine), 140.32 ( $\mathrm{C}^{6}$-pyridazine $), 141.96\left(\mathrm{C}^{3}\right.$ pyridazine $), 142.62 \mathrm{~d}\left(\mathrm{C}^{5}\right.$-furan, $\left.{ }^{4} J_{\mathrm{PC}}=2.9 \mathrm{~Hz}\right), 146.33 \mathrm{~d}$ $\left(\mathrm{C}^{2}\right.$-furan, $\left.{ }^{2} J_{\mathrm{PC}}=13.9 \mathrm{~Hz}\right), 167.39(\mathrm{C}=\mathrm{O}) .{ }^{31} \mathrm{P} \mathrm{NMR}$ spectrum $\left(\mathrm{CDCl}_{3}\right), \delta_{\mathrm{P}}$, ppm: 22.73 .

Ethyl 3-methyl-6-[4-(diethoxyphosphorylmethyl)fur-3-yl]pyridazin-4-carboxylate (5d). Yield 74\%, yellowish crystals, mp $102-103^{\circ} \mathrm{C} .{ }^{1} \mathrm{H}$ NMR spectrum $\left(\mathrm{CDCl}_{3}\right), \delta$, ppm: 1.17-1.28 m (9H, $\mathrm{CH}_{3}$-ester, $\mathrm{CH}_{3}$ phosphonate), $2.23 \mathrm{~s}\left(3 \mathrm{H}, \mathrm{CH}_{3}\right), 3.44 \mathrm{~d}\left(2 \mathrm{H}, \mathrm{CH}_{2} \mathrm{P}, J_{\mathrm{PH}}=\right.$ $20.4 \mathrm{~Hz}), 4.04$ d.q $\left(4 \mathrm{H}, \mathrm{CH}_{2} \mathrm{O}\right.$-phosphonate, $J_{\mathrm{HH}}=7.2 \mathrm{~Hz}$, $\left.J_{\mathrm{PH}}=14.8 \mathrm{~Hz}\right), 4.16 \mathrm{q}\left(\mathrm{CH}_{2} \mathrm{O}\right.$-ester, $\left.J_{\mathrm{HH}}=7.2 \mathrm{~Hz}\right), 7.45 \mathrm{~d}$ $\left(1 \mathrm{H}, \mathrm{H}^{5}\right.$-furan, $\left.J_{\mathrm{HH}}=2.0 \mathrm{~Hz}\right), 7.63 \mathrm{~s}\left(1 \mathrm{H}, \mathrm{H}^{5}\right.$-pyridazine $)$, 
8.16 br.s $\left(1 \mathrm{H}, \mathrm{H}^{5}\right.$-furan). ${ }^{13} \mathrm{C}$ NMR spectrum $\left(\mathrm{CDCl}_{3}\right)$, $\delta_{\mathrm{C}}$, ppm: $14.54\left(\mathrm{CH}_{3}\right.$-ester $), 16.31 \mathrm{~d}\left(\mathrm{CH}_{3}\right.$-phosphonate, $\left.{ }^{3} J_{\mathrm{PC}}=6.2 \mathrm{~Hz}\right), 17.54\left(\mathrm{CH}_{3}\right), 21.87 \mathrm{~d}\left(\mathrm{CH}_{2} \mathrm{P},{ }^{1} J_{\mathrm{PC}}=\right.$ $140.9 \mathrm{~Hz}), 59.57\left(\mathrm{CH}_{2} \mathrm{O}\right.$-ester $), 62.00 \mathrm{~d}\left(\mathrm{CH}_{2} \mathrm{O}-\right.$ phosphonate, $\left.{ }^{3} J_{\mathrm{PC}}=6.5 \mathrm{~Hz}\right), 113.71 \mathrm{~d}\left(\mathrm{C}^{4}\right.$-furan, ${ }^{2} J_{\mathrm{PC}}=$ $9.2 \mathrm{~Hz}), 123.04 \mathrm{~d}\left(\mathrm{C}^{3}\right.$-furan, $\left.{ }^{3} J_{\mathrm{PC}}=6.6 \mathrm{~Hz}\right), 124.75$ ( $\mathrm{C}^{5}$-pyridazine $), 128.28\left(\mathrm{C}^{4}\right.$-pyridazine $), 141.07\left(\mathrm{C}^{6}\right.$ pyridazine), $142.86 \mathrm{~d}\left(\mathrm{C}^{5}\right.$-furan, $\left.{ }^{3} J_{\mathrm{PC}}=7.6 \mathrm{~Hz}\right), 142.99$ ( $\mathrm{C}^{3}$-pyridazine), $146.45\left(\mathrm{C}^{2}\right.$-furan $), 167.56(\mathrm{C}=\mathrm{O}) .{ }^{31} \mathrm{P}$ NMR spectrum $\left(\mathrm{CDCl}_{3}\right), \delta_{\mathrm{P}}$, ppm: 27.43. Mass spectrum (ESI): found 405.1183, for $\mathrm{C}_{17} \mathrm{H}_{23} \mathrm{~N}_{2} \mathrm{O}_{6} \mathrm{P}$ calculated $405.1186[M+\mathrm{Na}]^{+}$.

Ethyl 3-methyl-6-[5-(diethoxyphosphorylmethyl)fur-3-yl]pyridazin-4-carboxylate 6d. Yield 28\%, light brown glass. ${ }^{1} \mathrm{H} \mathrm{NMR}$ spectrum $\left(\mathrm{CDCl}_{3}\right), \delta$, ppm: $1.25-$ $1.32 \mathrm{~m}\left(9 \mathrm{H}, \mathrm{CH}_{3}\right.$-ester, $\mathrm{CH}_{3}$-phosphonate), $2.26 \mathrm{~s}(3 \mathrm{H}$, $\left.\mathrm{CH}_{3}\right), 3.23 \mathrm{~d}\left(2 \mathrm{H}, \mathrm{CH}_{2} \mathrm{P}, J_{\mathrm{PH}}=21.2 \mathrm{~Hz}\right), 4.06-4.15 \mathrm{~m}$ $\left(4 \mathrm{H}, \mathrm{CH}_{2} \mathrm{O}\right.$-phosphonate), 4.19 q $\left(\mathrm{CH}_{2} \mathrm{O}\right.$-ester, $J_{\mathrm{HH}}=$ $7.2 \mathrm{~Hz}), 6.58 \mathrm{~d}\left(1 \mathrm{H}, \mathrm{H}^{4}\right.$-furan, $\left.J_{\mathrm{PH}}=3.2 \mathrm{~Hz}\right), 7.61 \mathrm{~s}(1 \mathrm{H}$, $\mathrm{H}^{5}$-pyridazine), $7.90 \mathrm{~s}\left(1 \mathrm{H}, \mathrm{H}^{5}\right.$-furan $) .{ }^{13} \mathrm{C} \mathrm{NMR}$ spectrum $\left(\mathrm{CDCl}_{3}\right), \delta_{\mathrm{C}}, \mathrm{ppm}: 14.12\left(\mathrm{CH}_{3}\right.$-ester $), 14.20\left(\mathrm{CH}_{3}\right.$-ester $)$, $16.39 \mathrm{~d}\left(\mathrm{CH}_{3}\right.$-phosphonate, $\left.{ }^{3} J_{\mathrm{PC}}=5.9 \mathrm{~Hz}\right), 17.70\left(\mathrm{CH}_{3}\right)$, $26.76 \mathrm{~d}\left(\mathrm{CH}_{2} \mathrm{P},{ }^{1} J_{\mathrm{PC}}=142.7 \mathrm{~Hz}\right), 59.36\left(\mathrm{CH}_{2} \mathrm{O}\right.$-ester $)$, $62.45 \mathrm{~d}\left(\mathrm{CH}_{2} \mathrm{O}\right.$-phosphonate, $\left.{ }^{3} \mathrm{~J}_{\mathrm{PC}}=6.5 \mathrm{~Hz}\right), 62.54 \mathrm{~d}$ $\left(\mathrm{CH}_{2} \mathrm{O}\right.$-phosphonate, $\left.{ }^{3} \mathrm{~J}_{\mathrm{PC}}=6.9 \mathrm{~Hz}\right), 106.19 \mathrm{~d}\left(\mathrm{C}^{4}\right.$-furan, $\left.{ }^{3} J_{\mathrm{PC}}=7.7 \mathrm{~Hz}\right), 123.16\left(\mathrm{C}^{5}\right.$-pyridazine $), 125.97 \mathrm{~d}\left(\mathrm{C}^{3}-\right.$ furan, $\left.{ }^{4} J_{\mathrm{PC}}=3.0 \mathrm{~Hz}\right), 128.50\left(\mathrm{C}^{4}\right.$-pyridazine $), 140.23\left(\mathrm{C}^{6}\right.$ pyridazine $), 141.18 \mathrm{~d}\left(\mathrm{C}^{2}\right.$-furan, $\left.{ }^{4} J_{\mathrm{PC}}=2.9 \mathrm{~Hz}\right), 146.57$ ( $\mathrm{C}^{3}$-pyridazine $), 147.22 \mathrm{~d}\left(\mathrm{C}^{5}\right.$-furan, $\left.{ }^{2} J_{\mathrm{PC}}=9.7 \mathrm{~Hz}\right)$, $167.55(\mathrm{C}=\mathrm{O}) .{ }^{31} \mathrm{P}$ NMR spectrum $\left(\mathrm{CDCl}_{3}\right), \delta_{\mathrm{P}}, \mathrm{ppm}$ : 22.64

\section{FUNDING}

The work was carried out with financial support of Russian Foundation for Basic Research (grant no. 19-08-01232) within the framework of the state task of the Ministry of Science and Higher Education of the Russian Federation (grant no. 785.00. $\mathrm{X} 6019$ ) using the equipment of the Engineering center of the St. Petersburg State Institute of Technology (Technical University).

\section{CONFLICT OF INTEREST}

No conflict of interest was declared by the authors.

\section{OPEN ACCESS}

This article is licensed under a Creative Commons Attribution 4.0 International License, which permits use, sharing, adaptation, distribution and reproduction in any medium or format, as long as you give appropriate credit to the original author(s) and the source, provide a link to the Creative Commons licence, and indicate if changes were made. The images or other third party material in this article are included in the article's Creative Commons licence, unless indicated otherwise in a credit line to the material. If material is not included in the article's Creative Commons licence and your intended use is not permitted by statutory regulation or exceeds the permitted use, you will need to obtain permission directly from the copyright holder. To view a copy of this licence, visit http://creativecommons.org/licenses/by/4.0/.

\section{REFERENCES}

1. Bennet, G.A., Mullen, G.B., Mitchell, J.T., Jones, W.A., and Allen, S.D., Eur. J. Med. Chem., 1989, vol. 24, no. 6, p. 579.

https://doi.org/10.1016/0223-5234(89)90024-X

2. Amador, A.G., Sherbrook, E.M., and Yoon, T.P., J. Am. Chem. Soc., 2016, vol. 138, no. 14, p. 4722.

https://doi.org/10.1021/Jacs.6b01728

3. Aljahdali, A.Z., Freedman, S.A., Li Miaosheng, and O'Doherty, G.A., Tetrahedron, 2018, vol. 74, no. 50, p. 7121.

https://doi.org/10.1016/J.tet.2018.10.036

4. Hulleatt, P.B., Khoo, M.L., Chua, Y.Y., Tan, T.W., Liew, R.S., Balogh, B., Deme, R., Matyus, P., and Chai, C.L.L., J. Med. Chem., 2015, vol. 58, no. 3, p. 1400. https://doi.org/10.1021/Jm501722s

5. Sherwood, A.M., Williamson, S.E., Johnson, S.N., Yilmaz, A., Day, V.W., and Prisinzano, T.E., J. Org. Chem., 2018, vol. 83, no. 2, p. 980. https://doi.org/10.1021/acs.Joc.7b02324

6. Pevzner, L.M., Russ. J. Gen. Chem., 2009, vol. 79, no. 3, p. 362.

https://doi.org/10.1134/S1070363209030050

7. Pevzner, L.M., Ignat'ev, V.M., and Ionin, B.I., Zh. Obshch. Khim., 1996, vol. 66, no. 5, p. 763.

8. Pevzner, L.M., Russ. J. Gen. Chem., 2013, vol. 83, no. 9 , p. 1687.

https://doi.org/10.1134/S1070363213090107

9. Pevzner, L.M. and Ponyaev, A.I., Russ. J. Gen. Chem., 2020, vol. 90, no. 8, p. 1453. https://doi.org/10.1134/S1070363220080125

10. Heinich, G. and Lotsch, G., Tetrahedron, 1985, vol. 41, no. 7, p. 1199.

https://doi.org/10.1016/S0040-4020(01)96521-4

11. Vors, J.-P., J. Heterocycl. Chem., 1991, vol. 28, no. 4, p. 1043.

https://doi.org/10.1002/J.het.5570280435 